\title{
Review of Green Food Processing techniques. Preservation, transformation, and extraction
}

\author{
Farid Chemat*, Natacha Rombaut, Alice Meullemiestre, Mohammad Turk, Sandrine Perino, \\ Anne-Sylvie Fabiano-Tixier, Maryline Abert-Vian \\ Université d'Avignon et des Pays de Vaucluse, INRA, UMR408, GREEN Team Extraction, F-84000 Avignon, France
}

\begin{abstract}
A B S T R A C T
This review presents innovative food processing techniques and their role in promoting sustainable food industry. These techniques (such as microwave, ultrasound, pulse electric field, instant controlled pressure drop, supercritical fluid processing) in the frontiers of food processing, food chemistry, and food microbiology, are not new and were already used for $>30$ years by academia and industry. We will pay special attention to the strategies and the tools available to make preservation, transformation and extraction greener and present them as success stories for research, education and at industrial scale. The design of green and sustainable processes is currently a hot research topic in food industry. Herein we aimed to describe a multifaceted strategy (innovative technologies, process intensification, bio-refinery concept) to apply this concept at research, educational, and industrial level.

Industrial relevance: Green Food Processing could be a new concept to meet the challenges of the 21st century, to protect both the environment and consumers, and in the meantime enhance competition of industries to be more ecologic, economic and innovative. This green approach should be the result of a whole chain of values in both senses of the term: economic and responsible, starting from the production and harvesting of food raw materials, processes of preservation, transformation, and extraction together with formulation and marketing.
\end{abstract}

Keywords:

Green Food Processing

Preservation

Transformation

Extraction

Innovative techniques

Intensification

Bio-refinery

\section{Introduction}

Food products, such as fruit and vegetables, fat and oils, sugar, dairy, meat, coffee and cocoa, meal and flours, are complex mixtures of vitamins, sugars, proteins and lipids, fibres, aromas, pigments, antioxidants, and other organic and mineral compounds. Before such products can be commercialized, they have to be processed and preserved for food ready meals and extracted for food ingredients. Different methods can be used for this purpose, e.g. frying, drying, filtering, and cooking. Nevertheless, many food ingredients and products are well known to be thermally sensitive and vulnerable to chemical, physical and microbiological changes. Losses of some nutritional compounds, low production efficiency, time- and energy-consuming procedures (prolonged heating and stirring, use of large volumes of water...) may be encountered using these conventional food-processing methods. These shortcomings have led to the use of new sustainable "green and innovative" techniques in processing, pasteurization and extraction, which typically involve less time, water and energy, such as ultrasound-assisted processing, supercritical fluid extraction and processing, microwave processing, controlled pressure drop process, and pulse electric field. The tremendous efforts made on greening food process can be evaluated through the consideration of books and journals devoted to these aspects (Chemat, Huma, \& Khan, 2011).

Food technology under extreme or non-classical conditions is currently a dynamically developing area in applied research and industry. Alternatives to conventional processing, preservation and extraction procedures may increase production efficiency and contribute to environmental preservation by reducing the use of water and solvents, elimination of wastewater, fossil energy and generation of hazardous substances. Within those constraints, "Green Food Processing" has to be introduced on the basis of green chemistry and green engineering: "Green Food Processing is based on the discovery and design of technical processes which will reduce energy and water consumption, allows recycling of by-products through bio-refinery, and ensure a safe and high quality product" (Fig. 1).

This review presents a complete picture of current knowledge on Green Food Processing techniques for preservation, transformation and extraction as success stories for research, education and at industrial scale. The readers like chemists, biochemists, chemical engineers, 
Version définitive du manuscrit publiée dans / Final version of the manuscript published in :

Innovative Food Science and Emerging Technologies (2017), Vol. 41, p. 357-377,

DOI: 10.1016/j.ifset.2017.04.016, Journal homepage : http://www.elsevier.com/locate/ifset

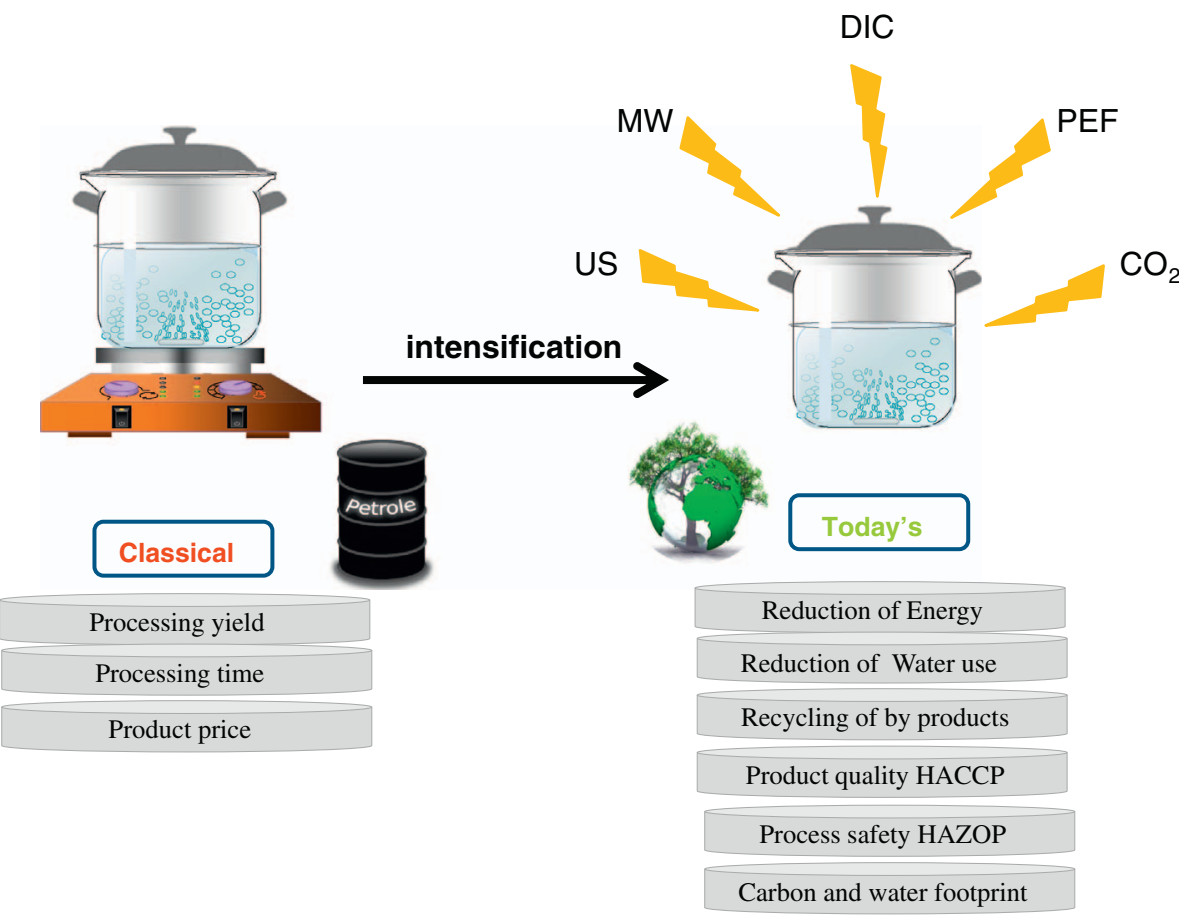

Fig. 1. Green Food Processing: evolution or revolution.

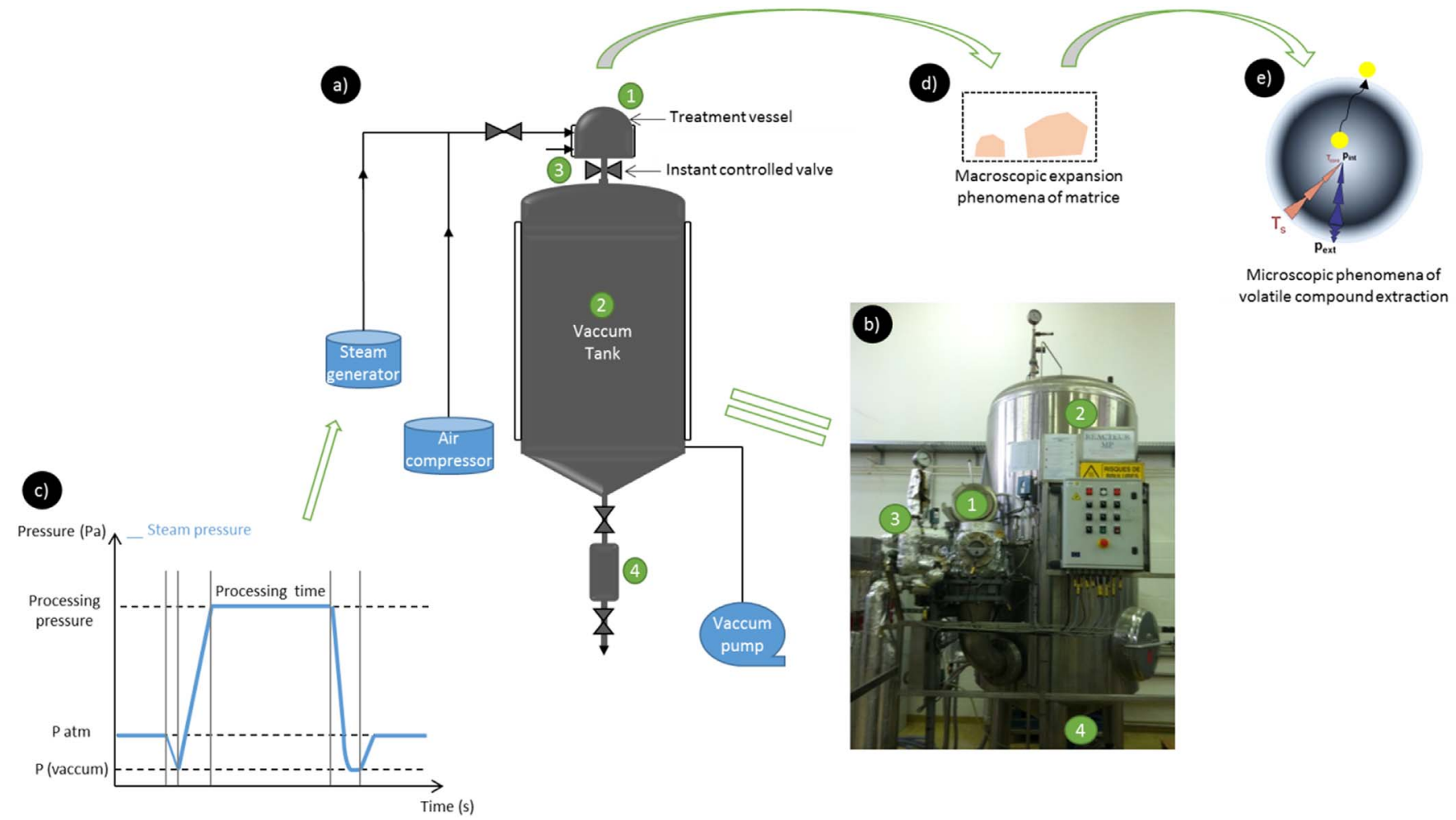

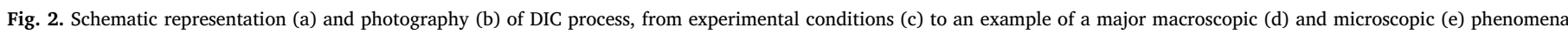
generated by DIC treatment.

physicians, and food technologists even from academia or industry will find the major solutions identified to design and demonstrate Green Food Processing on laboratory, classroom and industrial scale to approach an optimal consumption of raw food materials, water and energy: (1) improving and optimization of existing processes; (2) using non-dedicated equipment; and (3) innovation in processes and procedures.

\section{Instant controlled pressure drop technology}

\subsection{Process and procedure}

DIC 'Détente Instantanée Contrôlée', French for Instant Controlled Pressure-Drop is based on the main principle of the thermodynamics of instantaneity and auto-vaporization processing combining with hydro- 
Innovative Food Science and Emerging Technologies (2017), Vol. 41, p. 357-377, DOI: 10.1016/j.ifset.2017.04.016, Journal homepage : http://www.elsevier.com/locate/ifset

thermo-mechanical evolution of many biopolymers for food, cosmetic, and pharmaceutical purposes. Developed by Allaf and Vidal (1989), DIC's research began by fundamental studies regarding expansion through alveolation and has targeted several applications in response to issues of control and quality improvement. DIC is considered as a high temperature/high pressure - short time (HTST) treatment and consists of thermo-mechanical processing induced by subjecting the raw material to saturated steam for a short period, and followed by an abrupt pressure drop towards vacuum (about $5 \mathrm{kPa}$ with a rate $>0.5$ MPa.s ${ }^{-1}$ ). Typically, the sample was adjusted to about $30 \%$ dry basis and submitted to a first pressure drop in the treatment vessel to be preconditioned. Then, the sample is subjected to heating under high saturated pressure (up to $1 \mathrm{MPa}$ ) at high temperature (up to $180{ }^{\circ} \mathrm{C}$ ) during a short time (5 to $60 \mathrm{~s}$ ) and followed by an abrupt pressure drop to vacuum (3-5 $\mathrm{kPa}, \Delta \mathrm{t}=20-200 \mathrm{~ms})$. The abrupt pressure drop ( $\Delta \mathrm{P}$ / $\Delta \mathrm{t}>25.10^{6} \mathrm{~Pa} . \mathrm{s}^{-1}$ ) induces a significant mechanical stress related to instant auto-vaporization of water, an instantaneous cooling of the sample, and swelling phenomenon, causing the rupture of cells and secretion of metabolites through cell walls (Allaf et al., 2011). The purpose of these effects leads to texture change, which results in higher porosity, as well as increased specific surface area and reduced diffusion resistance of the sample. Experimental conditions of DIC extraction allow reduced processing time and the instant reducing temperature drops prevent further thermal deterioration and ensure a high quality of extract (Haddad, Louka, Gadouleau, Juhel, \& Allaf, 2001)

DIC equipment is composed of four major components (Fig. 2): (1) an extraction vessel, which is an autoclave with a heating jacket where the sample to be treated is placed; (2) a controlled pressure-drop valve, which ensures a quick and controlled liberation of steam pressure contained in the extraction vessel to the vacuum pump; (3) a vacuum system composed of a vacuum pump and a tank with a volume 50 -fold higher than the volume of the treatment vessel; (4) an extract collection trap used to recover condensates; a water ring pump maintains the tank pressure at about $5 \mathrm{kPa}$. At the beginning, humidified product is placed in the autoclave at atmospheric pressure before vacuum setting. Initial vacuum ensures closer contact of the fluid heating with the exchange surface, which enhances the heat transfer in raw material. After closing the valve (between the autoclave and the vacuum tank), the autoclave is filled with steam up to a processing pressure. After this treatment time, the controlled pressure-drop valve is instantaneously opened (in $<200 \mathrm{~ms}$ ), resulting in an abrupt pressure drop inside the treatment vessel. After steam release, the atmospheric pressure is returned back inside the reactor.

\subsection{Applications in food processing}

DIC treatment is employed in several industrial fields such as food, cosmetic, pharmaceutic in response to issues of control and quality improvement, coupled with reduced energy costs (Allaf \& Allaf, 2014). As shown in Table 1, DIC can be used in various operations such as transformation, preservation, and extraction. For each operation the approach has always induced the integration of phenomena of instantaneity to intensify the elementary processes of transfer.

The DIC treatment combined to classical hot air drying may be considered as the tool of intensifying the drying when the kinetics of dehydration is particularly low due to difficulty of water transfer through material because of resistance of the natural structure of the material. Recently, Mounir and Allaf (2008) propose an innovative process of 3-stage spray-drying using DIC treatment of powders (sodium caseinates, whey proteins), using saturated steam as a texturing fluid which can permit the modification of powder granule structure, and allows the formation of vacuoles and pores. DIC increases the specific surface area of spray-dried powder and consequently overcomes the problems related to the presence of fine powder (dustiness). DIC treatment appears to be a good alternative to expand granule powder of heat-sensitive food such as apple and onion (Mounir, Besombes, AlBitar, \& Allaf, 2011). After an initial partial drying step, DIC treatment permits the improvement of dehydration kinetic inserting a texturing process allowing the partially dried product to be expanded. The second step of drying (after DIC treatment) is greatly reduced from $6 \mathrm{~h}$ (untreated apple) to $1 \mathrm{~h}$ in the case of treated-sample. In the case of onion, the effective diffusivity is accelerated after DIC treatment $\left(7.56 \cdot 10^{-10}\right.$ as against $0.46 \cdot 10^{-10} \mathrm{~m}^{2} \cdot \mathrm{s}^{-1}$ for untreated sample. At equal water content $(100 \% \mathrm{db}$.), DIC pretreatment with a pressure comprised between 0.1 and $0.3 \mathrm{MPa}$ and a short heating period of few seconds (5 to $45 \mathrm{~s}$ ) combined to freezing and thawing allows improvement of drying/rehydration operations for apple with a good preservation of textural properties. DIC is considered as a good alternative process to classical hot air drying and freeze-drying, especially for drying fragile fruit, such as strawberries (AlonzoMacías, Cardador-Martínez, Mounir, Montejano-Gaitán, \& Allaf, 2013). Furthermore, DIC coupled to hot air drying allows to preserve the nutritional value and bioactive molecules, at optimal DIC conditions $(0.35 \mathrm{MPa}$ for $10 \mathrm{~s})$, treated strawberries were richer in anthocyanins and phenolic compounds as compare to other classical drying methods.

DIC is recognized as a process for decontamination, debacterization of foodstuffs. Three patents protect this application (Allaf, Debs-Louka, Louka, Cochet, \& Abraham, 1994; Allaf et al., 1998). The treatment allows DIC the elimination of micro-organisms (even in spore forms) through two main mechanisms: a controlled thermal treatment; pressure relaxation excessively stressed on microorganisms that cause their explosion (Debs-Louka, Louka, Abraham, \& Allaf, 2010). Archeological investigations often renew pieces of wood having spent long periods in water (mostly seawater). The DIC treatment can stop these degradations and stabilize the archeologiocal waterlogged woods originated from different museums (Allaf, Rezzoug, Cioffi, Louka, \& Sanya, 1999; Sanya, Rezzoug, \& Allaf, 1998). In the case of thermal treatment for allergen in peanuts, lentil, chickpeas and soybeans proteins, DIC treatment produces a reduction in the overall in vitro IgE binding. Immunoreactivity of soybean proteins was almost abolished with a treatment at 6 bars for $3 \mathrm{~min}$. Additionally, DIC treatment $(0.4 \mathrm{MPa}$ during $25 \mathrm{~s}$ ) showed decrease in the IgE binding of whey proteins ( $\beta$ lactoglobulin and $\alpha$-lactalbumin) and a greater reduction of the allergenicity of whey proteins (Boughellout et al., 2015).

DIC pretreatment is considered an efficient method for extraction and texturing from various vegetal materials. Indeed, Mkaouar, Bahloul, Gelicus, Allaf, and Kechaou (2015) showed that DIC texturing on the solvent extraction of polyphenols from olive leaves improves the yield of extraction of $312 \%$ and permits generating extract richer in bioactive compounds. Another study has proved that DIC allows enhancing lipid extraction from jatropha and rapeseed seeds without significant modification of fatty acids composition in comparison with conventional Soxhlet extraction (Nguyen Van, 2010). Allaf et al. (2014) have shown that enhancing of lipid extraction by DIC treatment is clearly noticed by calculation of effective diffusivity. DIC process is a good solution for deodorizing and expanse the vegetal matrix in the same time before improving antioxidant extraction from rosemary leaves (Allaf et al., 2013). Expansion of raw material permits a better diffusion of solvent through the material and accelerates the extraction of bioactive compound from $4 \mathrm{~h}$ for hydrodistillation to $3 \mathrm{~min}$ with DIC. More recently, DIC was endorsed as a pretreatment for in-situ transesterification in the case of microalgae. Optimized DIC treatment $(\mathrm{P}=0.16 \mathrm{MPa}$ and $\mathrm{t}=68 \mathrm{~s}$ ) allows increasing of $27 \%$ in total lipid and $>75 \%$ in fatty acids methyl esters yield (Kamal, Besombes, \& Allaf, 2014). Additionally, to lipid extraction, it was observed that the residual microalgae allow increasing of lutein extraction. Moreover, DIC allows reducing the energy consumption and manufacturing cost compared to conventional processes of lipid extraction. 
Version définitive du manuscrit publiée dans / Final version of the manuscript published in :

Innovative Food Science and Emerging Technologies (2017), Vol. 41, p. 357-377,

DOI: 10.1016/j.ifset.2017.04.016, Journal homepage : http://www.elsevier.com/locate/ifset
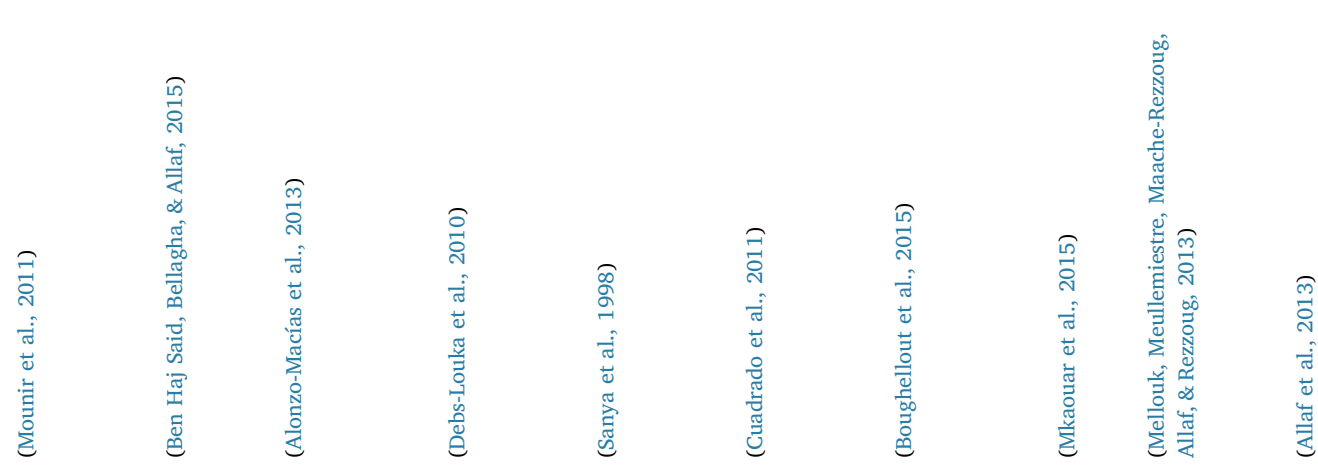

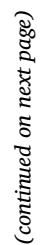
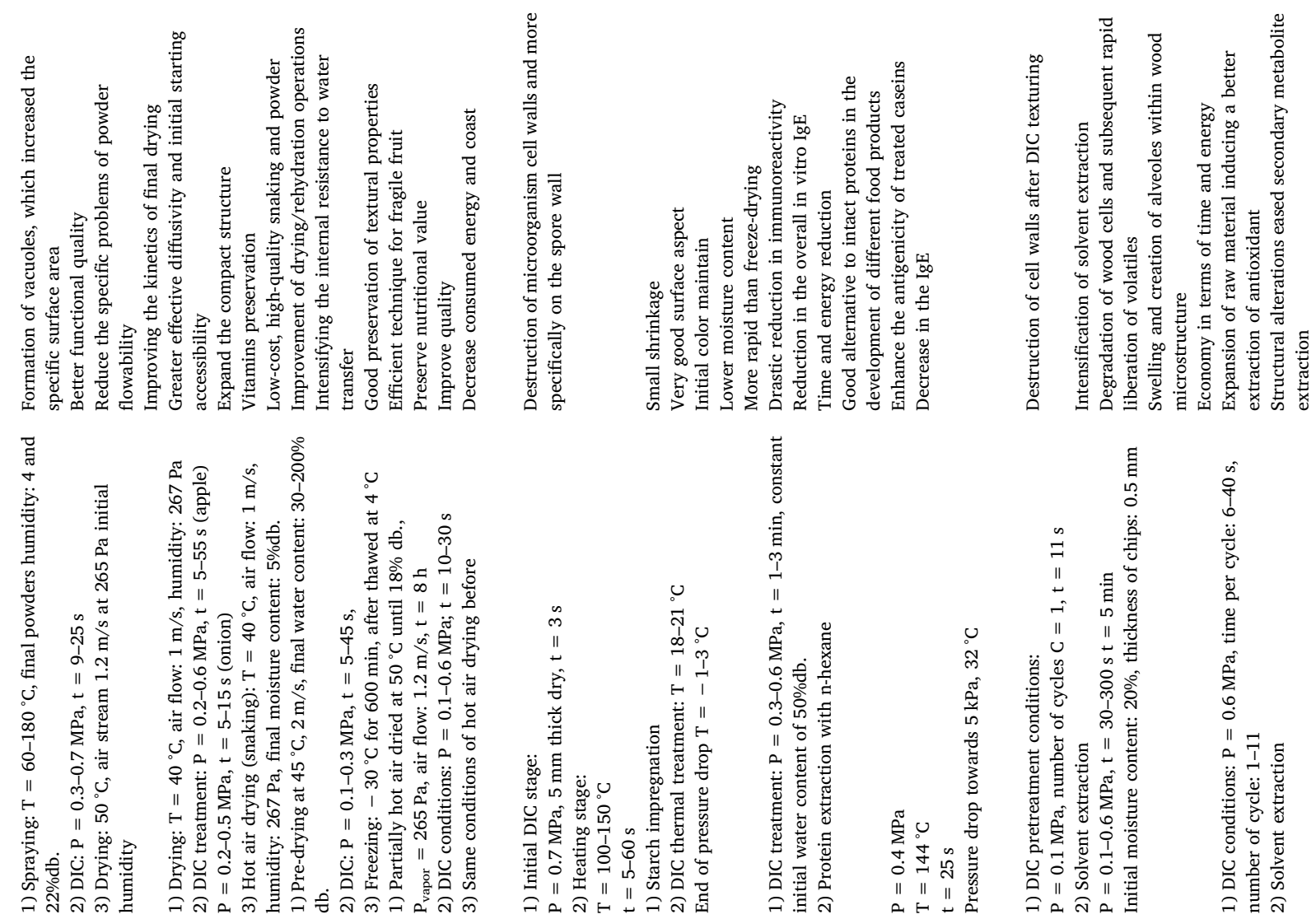

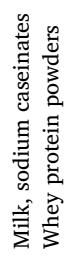

营

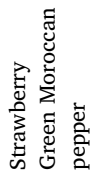

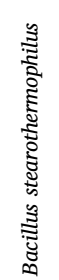
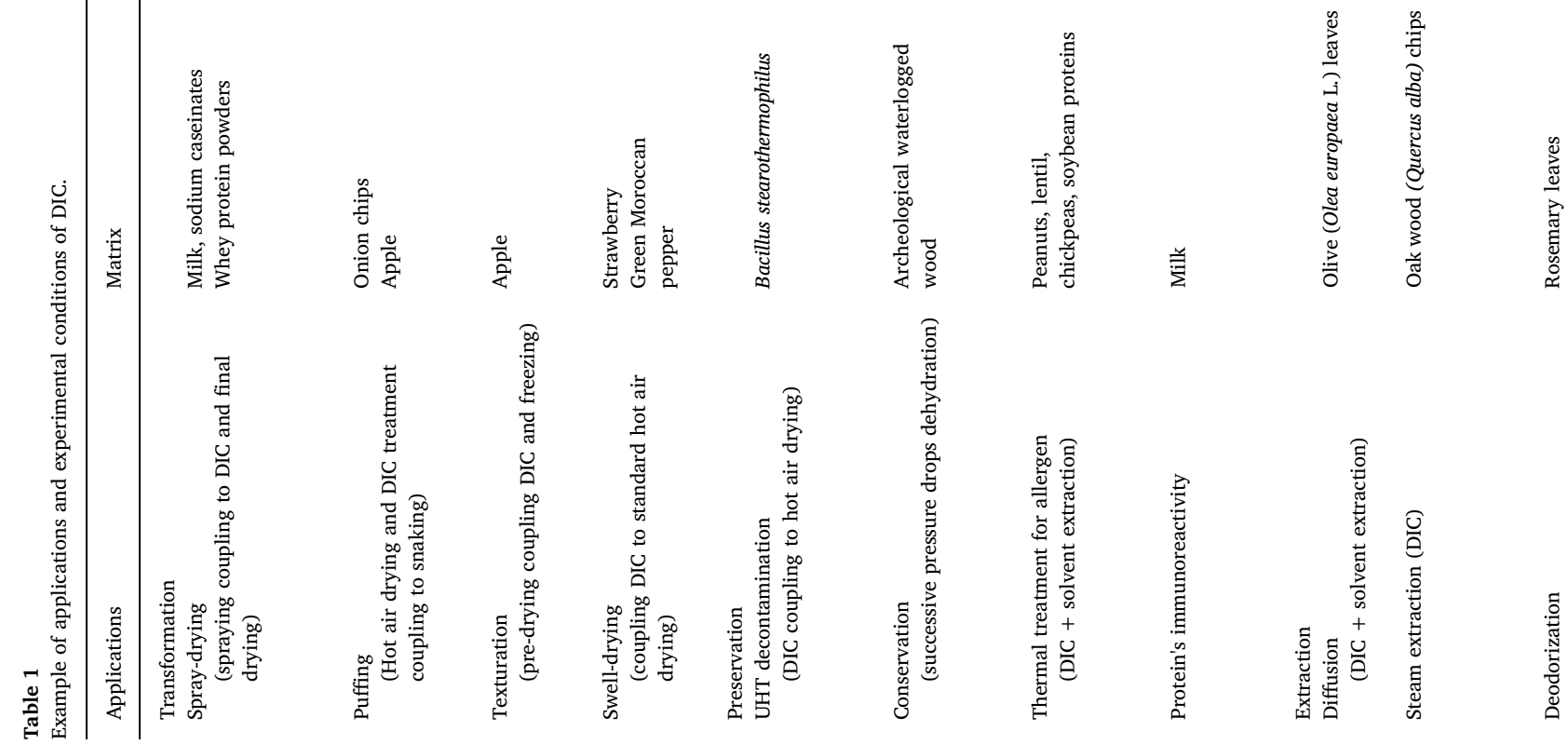

Comment citer ce document: 


\section{$\mid+2.3$. Success story}

The technology of instant controlled pressure drop has been generated by Allaf group since 1988, several industrial projects have been developed. Many patents have been filed since 1993 (Allaf et al., 1994) and more than twenty PhD theses have treated the subject from different angles. Today, the Allaf group provides research while participating in the design of machinery and the transition from laboratory studies to the industrial stage. The process is operated by ABCAR-DIC Process company, localized in La Rochelle (France). Swelldrying is largely used at industrial scale to produce swell-dried products of $>200$ varieties such as apple, banana, strawberry, onion, tomato etc. in the form of cubes, slices and powder that is found in healthy food and unique bands known like "greedy snacking", "fruit snacks" or "vegetable petals." This process was also used for decontamination, dehydration and texturation of many foodstuffs. Furthermore, intermediate food products obtained after DIC treatment are used for the development of dehydrated meals or dairy products. The DIC technology is also largely used for the post-harvest rice processing. The USDA report says that Egypt's rice paddy production in the year May 2012 to April 2013 is expected to rise to 6.37 million tons of dried paddy rice, i.e., 4.5 million tons of dried unbroken white grain DIC rice. In China, many teabags treated by DIC have been commercialized and allow a greater diffusion of tea in water and even in cold water (Allaf \& Allaf, 2014).

\section{Pulsed Electric Field}

Pulsed Electric Field (PEF) treatment, also referred as electroporation or electropermeabilization, is a nonthermal process where an external electric field is applied to a living cell for a very short duration (from several nanoseconds to several milliseconds) (Fig. 3). The exact mechanism of membrane permeabilization is not precisely understood yet, but it is accepted that electroporation consists of four different stages including (Saulis, 2010): (a) increase of the transmembrane potential of the cytoplasmic membrane due to cell membrane charging by the applied external electric field, (b) creation of small metastable hydrophilic pores if a threshold of transmembrane potential is reached $(0.2-1.0 \mathrm{~V})$, (c) evolution of the number and/or size of the created pores during the PEF treatment, and (d) PEF post treatment stage with leakage of intracellular compounds, entrance of extracellular substances i.e. as irreversible electroporation or pore resealing and integrity recovering of membrane i.e. reversible electroporation.

The effectiveness of cell membranes electropermeabilization depends on several process parameters (electric field strength, treatment time, specific energy, pulse shape, pulse width, frequency and temperature), treatment mode (batch, continuous), configuration of treatment chamber (collinear, coaxial and parallel) (Van den Bosch, 2007), physicochemical characteristics of the treated matrix ( $\mathrm{pH}$ and conductivity), characteristics of the treated cells (size, shape, membrane, and envelope structure) and state (suspension, solid, semi-solid) (Vorobiev \& Lebovka, 2009).

$\mathrm{PEF}$ is a promising green tool in food processing as its opens a wide range of application due to the described phenomenon of cell membrane increased permeability or disruption via electroporation. The application can be classified depending on the extent of the applied external electric field and specific energy (Toepfl, Heinz, \& Knorr, 2006). For instance, the application of low electric treatment ( $\mathrm{E}<2 \mathrm{kV} / \mathrm{cm} ; \mathrm{Q}<5 \mathrm{~kJ} / \mathrm{kg}$ ) is known to induce stress response on the cellular level and is routinely used in molecular biology to gain access to the cytoplasm in order to introduce different molecules. The applications in this field are rather scarce and are limited to biological reaction enhancement of vegetable and microbial cells. The improvement of mass transfer is generally dependent on higher electric fields $(0.1<\mathrm{E}<50 \mathrm{kV} / \mathrm{cm} ; 0.4<\mathrm{Q}<60 \mathrm{~kJ} / \mathrm{kg})$. Food preservation due to microbial or enzyme inactivation requires the highest level of 
Version définitive du manuscrit publiée dans / Final version of the manuscript published in :

Innovative Food Science and Emerging Technologies (2017), Vol. 41, p. 357-377,

DOI: 10.1016/j.ifset.2017.04.016, Journal homepage : http://www.elsevier.com/locate/ifset

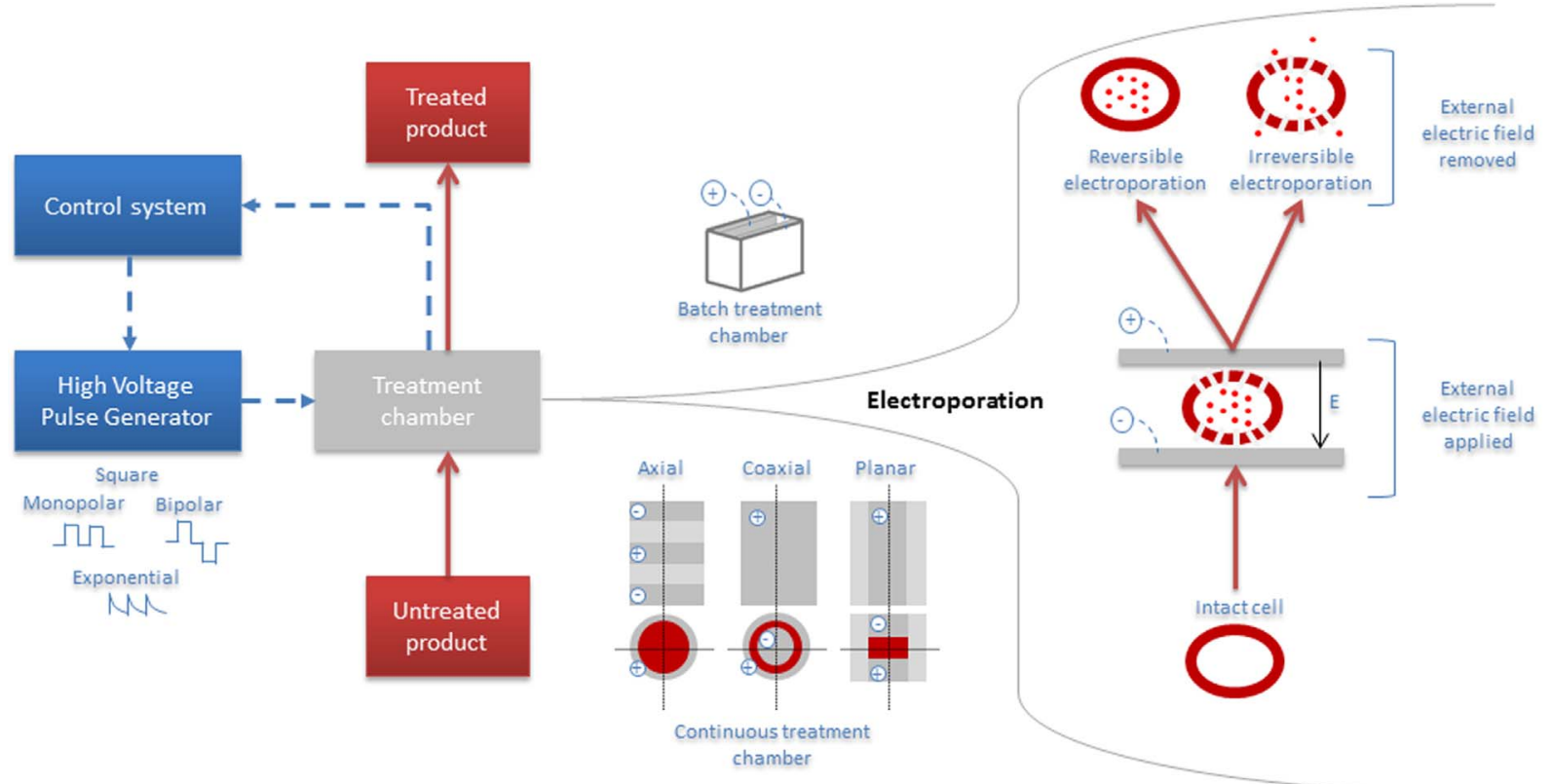

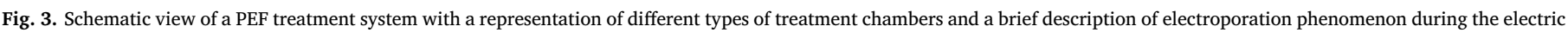
treatment.

Table 2

Example of applications and experimental conditions of PEF.

\begin{tabular}{|c|c|c|c|c|}
\hline Application & Matrix & Treatment conditions & Benefits & Reference \\
\hline \multicolumn{5}{|l|}{ Preservation } \\
\hline \multirow[t]{2}{*}{ Inactivation } & $\begin{array}{l}\text { Ringer solution } \\
\text { contaminated with } B \text {. } \\
\text { subtilis spores }\end{array}$ & $\begin{array}{l}\text { (PEF + heat }) \\
6<\mathrm{E}<11 \mathrm{kV} / \mathrm{cm} \\
\mathrm{Q}<350 \mathrm{~kJ} / \mathrm{kg}\end{array}$ & Inactivation of spores with reduced heat load & (Siemer, Toepfl, \& Heinz, 2014) \\
\hline & Carrot puree & $\begin{array}{l}\text { (Chilling + PEF) } \\
0.1<\mathrm{E}<1.1 \mathrm{kV} / \mathrm{cm} \\
0.15<\mathrm{Q}<15.58 \mathrm{~kJ} / \mathrm{kg}\end{array}$ & $\begin{array}{l}\text { Improvement of the stability of vitamin } C \text { and } \\
\text { reduction of the residual activity of AAO and } \\
\text { POD }\end{array}$ & $\begin{array}{l}\text { (Leong, Oey, Clapperton, } \\
\text { Aganovic, \& Toepfl, 2015) }\end{array}$ \\
\hline Freezing/thawing & Apple; spinach & $\begin{array}{l}\text { (PEF + impregnation + freezing } \\
+ \text { thawing) } \\
0.58<\mathrm{E}<0.8 \mathrm{kV} / \mathrm{cm} \text {; Q: n.d. }\end{array}$ & $\begin{array}{l}\text { Acceleration of freezing/thawing process and } \\
\text { comparable texture after defrosting to fresh } \\
\text { samples }\end{array}$ & $\begin{array}{l}\text { (Parniakov et al., 2016a; Phoon et al., } \\
\text { 2008) }\end{array}$ \\
\hline $\begin{array}{l}\text { Osmotic } \\
\text { dehydration }\end{array}$ & Apple, carrot & $\begin{array}{l}\text { (PEF }+ \text { impregnation }) \\
0.22<\mathrm{E}<10 \mathrm{kV} / \mathrm{cm} \\
0.15<\mathrm{Q}<106.7 \mathrm{~kJ} / \mathrm{kg}\end{array}$ & $\begin{array}{l}\text { Increase of water loss } \\
\text { Solute uptake by the matrix depends on the } \\
\text { matrix and operational conditions }\end{array}$ & $\begin{array}{l}\text { (Rastogi et al., 1999; Wiktor et al., } \\
\text { 2014) }\end{array}$ \\
\hline Convective drying & Carrot, red pepper & $\begin{array}{l}(\mathrm{PEF}+\text { hot air drying }) \\
0.5<\mathrm{E}<2.5 \mathrm{kV} / \mathrm{cm} \\
1.8<\mathrm{Q}<56.5 \mathrm{~kJ} / \mathrm{kg}^{\mathrm{a}}\end{array}$ & $\begin{array}{l}\text { Increase of drying rates and color quality (red } \\
\text { pepper) }\end{array}$ & $\begin{array}{l}\text { (Gachovska et al., 2008; Won et al., } \\
\text { 2015) }\end{array}$ \\
\hline \multicolumn{5}{|l|}{ Extraction } \\
\hline Diffusion & Grape pomace, sugar beet & $\begin{array}{l}\text { (PEF }+ \text { extraction by diffusion }) \\
0.6<\mathrm{E}<3 \mathrm{kV} / \mathrm{cm} \text {; } \\
\mathrm{Q}<19.4 \mathrm{~kJ} / \mathrm{kg}\end{array}$ & $\begin{array}{l}\text { Increase of polyphenols and sucrose } \\
\text { concentration; selective extraction towards } \\
\text { anthocyanins, lower coloration and better } \\
\text { filtrability of juices (sugar beet) }\end{array}$ & $\begin{array}{l}\text { (Brianceau et al., 2015; Loginova } \\
\text { et al., 2011) }\end{array}$ \\
\hline Expression & Apple, grape & $\begin{array}{l}\text { (PEF + extraction by pressing) } \\
0.4<\mathrm{E}<0.65 \mathrm{kV} / \mathrm{cm} \\
15<\mathrm{Q}<32 \mathrm{~kJ} / \mathrm{kg}\end{array}$ & $\begin{array}{l}\text { Increase of juice and polyphenol yield, decrease } \\
\text { of juice turbidity and better odor intensity }\end{array}$ & $\begin{array}{l}\text { (Grimi, Lebovka, } \\
\text { Vorobiev, \& Vaxelaire, 2009; Turk } \\
\text { et al., 2012) }\end{array}$ \\
\hline Filtration & BSA suspension & $\begin{array}{l}(\mathrm{PEF}+\text { cross flow UF }) \\
\mathrm{E}=4.5 \mathrm{kV} / \mathrm{cm}, \mathrm{Q}: \text { n.d. }\end{array}$ & $\begin{array}{l}\text { Improvement of concentrating rate of protein in } \\
\text { retentate and reducing the solute-related } \\
\text { resistance to the permeate flux }\end{array}$ & (Robinson et al., 1993) \\
\hline Distillation & Roses (R. alba L.) & $\begin{array}{l}\mathrm{E}=25 \mathrm{kV} / \mathrm{cm}, 10<\mathrm{Q}<20 \mathrm{~kJ} / \\
\mathrm{kg}\end{array}$ & $\begin{array}{l}\text { Increase of oil essential oil yield and possible } \\
\text { reduce of distillation time }\end{array}$ & (Dobreva et al., 2010) \\
\hline \multicolumn{5}{|l|}{ Transformation } \\
\hline Cutting & Carrot & $\mathrm{E}=0.8 \mathrm{kV} / \mathrm{cm}, \mathrm{Q}<166 \mathrm{~kJ} / \mathrm{kg}$ & Decrease of the cutting force & (Leong et al., 2014) \\
\hline Softening & Meat & $0.32<\mathrm{E}<0.48 \mathrm{kV} / \mathrm{cm} ; \mathrm{Q} /$ n.d. & Improving meat tenderness & (Bekhit et al., 2016) \\
\hline Frying & Potato & $\begin{array}{l}0.75<\mathrm{E}<2.5 \mathrm{kV} / \mathrm{cm} ; \mathrm{Q}: \\
18.9 \mathrm{~kJ} / \mathrm{kg}\end{array}$ & $\begin{array}{l}\text { Improving potato color and reducing oil uptake } \\
\text { after frying }\end{array}$ & (Ignat et al., 2015) \\
\hline Fermentation & S. cerevisiae & $100<\mathrm{E}<6 \mathrm{kV} / \mathrm{cm}$; Q: n.d. & $\begin{array}{l}\text { Increase of sugars consumption, decrease of } \\
\text { fermentation time }\end{array}$ & (Mattar et al., 2015) \\
\hline
\end{tabular}

${ }^{\text {a }}$ Data not available in (Won et al., 2015). 
Innovative Food Science and Emerging Technologies (2017), Vol. 41, p. 357-377, DOI: 10.1016/j.ifset.2017.04.016, Journal homepage : http://www.elsevier.com/locate/ifset

treatment $(2<\mathrm{E}<90 \mathrm{kV} / \mathrm{cm} ; 50<\mathrm{Q}<44,000 \mathrm{~kJ} / \mathrm{kg})$.

\subsection{Food preservation}

Food preservation (Table 2) is achieved whether by controlling or by inhibiting external contaminants and/or internal biological reactions that could alter the organoleptic and nutritional quality of food. For this, two main strategies are being used: a) applying thermal treatments; b) decreasing the water activity of the food matrix to inhibit biological reactions.

Non-thermal PEF processing in liquid foods and beverages preservation has been thoroughly studied as an alternative method to heat preservation. A wide variety of vegetative microorganisms and enzymes have been successfully treated in different food matrices (Griffiths \& Walkling-Ribeiro, 2014; Martín-Belloso, MarsellésFontanet, \& Elez-Martínez, 2014; Terefe, Buckow, \& Versteeg, 2015). Better quality retention in PEF-processed products compared to thermal processing has been observed in many cases. However, PEF has often little or a limited effect on enzymes at processing conditions sufficient for microbial inactivation (50-1000 kJ/kg). At sufficiently high-specific energy input (e.g. $>1000 \mathrm{~kJ} / \mathrm{kg}$ ), PEF causes significant inactivation of enzymes at ambient and mild temperature conditions (Terefe et al., 2015). Commercial PEF treatment systems operate in continuous mode for high productivity. Generally, PEF treated liquid food is packaged after their preservative treatment. A batch treatment mode, in conductive plastic material, could also be achieved with comparable levels of inactivation (Roodenburg et al., 2013).

Depending on the required inactivation, target, product composition and initial temperature, it may be advantageous to combine PEF treatment with other treatments (heat, $\mathrm{pH}$, antimicrobial). Such combinations may provide the required lethality at lower field strength and with less electrical energy (Álvarez \& Heinz, 2007).

Because of their rigid structures, bacterial spores can survive harsh environments for a long period of time. The combination of temperature and electric fields $>60{ }^{\circ} \mathrm{C}$ and $30 \mathrm{kV} / \mathrm{cm}$ respectively was effective on spore inactivation (Siemer, Aganovic, Toepfl, \& Heinz, 2015).

The main strength seems to be in PEF ability to affect less the nutritional and sensory properties of food material as compared to thermal treatment. For instance, PEF treated beverages seem to have higher contents of polyphenols, carotenoids and vitamins compared to heat pasteurization (Tokusoglu, Odriozola-Serrano, \& Martín-Belloso, 2014).

Freezing is a widespread method for food preservation. Unluckily, such treatment leads to deterioration of food texture and flavors during subsequent transformation operations. The formation, the size of crystals and recrystallization after freezing are the main reasons of the quality loss of frozen foods. Reversible electroporation, due to its transient increase in membrane permeabilization, enables introduction of cryoprotectants into biological cells. This family of molecules prevents crystal formation during freezing. This combination leads to a noticeable acceleration of the freezing/thawing process (Jalté, Lanoisellé, Lebovka, \& Vorobiev, 2009; Parniakov, Bals, Lebovka, \& Vorobiev, 2016a), increase of freezing temperature and a decrease of the ice propagation rate (Dymek, Dejmek, Galindo, \& Wisniewski, 2015). Texture and firmness of spinach leaves (Phoon, Galindo, Vicente, \& Dejmek, 2008), potato strips were retained by impregnating the material with trehalose (Shayanfar, Chauhan, Toepfl, \& Heinz, 2013) and apples with glycerol (Parniakov et al., 2016a).

Dehydration is probably the oldest means for food preservation. The intact cell membranes in food materials represent a highly limiting factor (barrier) to water transport during drying of food matrices. Pore formation during PEF treatment increases cell membrane permeability which enhances the mass transport phenomena. PEF treatment was successfully combined with traditional processes such as osmotic dehydration, freeze drying, radiant and convective heat. The results are encouraging as the combination of PEF and osmotic dehydration resulted in an increase of water loss and migration of solutes into the food matrix was observed (Rastogi, Eshtiaghi, \& Knorr, 1999; Wiktor, Śledź, Nowacka, Chudoba, \& Witrowa-Rajchert, 2014). A significant reduction of energy consumption and an acceleration of cooling and drying time could also be achieved when apples and potatoes are electrically treated prior to freeze drying without alteration of the dried samples shape (Parniakov, Bals, Lebovka, \& Vorobiev, 2016b; Wu \& Zhang, 2014). Similar observations were reported for radiant (Baier, Bußler, \& Knorr, 2015) and convective air drying (Gachovska, Adedeji, Ngadi, \& Raghavan, 2008; Won, Min, \& Lee, 2015). PEF treatment was beneficial to color quality of air-dried products (Won et al., 2015).

\subsection{Extraction}

Extraction by solvents (diffusion) and force fields (pressing, filtration, and centrifugation) is widely used for production of liquid foods and beverages as well as for extraction of molecules of industrial interest. Pretreatments that modify the permeability of the cell membranes, such as grinding, heating, or enzymatic treatment, enhance the mass transfer. However, these techniques may require a significant amount of energy and can cause losses of valuable food compounds.

The use of PEF became very popular in this field as it allows critical acceleration of the solid-liquid extraction. Different technologies of agro-industrial extraction become more selective and less energy consuming if PEF is applied (Vorobiev \& Lebovka, 2015).

The combination of PEF and extraction by diffusion has been investigated for improving the extraction of different compounds located on the inside of plant cells, such as colorants (chlorophylls, carotenoids, betalains...), sucrose, polyphenols and other secondary metabolites (Puértolas, Luengo, Álvarez, \& Raso, 2012). PEF pretreatment can be applied for winemaking prior to the macerating fermentation step, the extraction of polyphenols is improved and the wine resulting has different organoleptic (color) attributes (El Darra et al., 2016). The same pretreatment is applied to traditional wine making residues; an enhancement of the selectivity of colorant (anthocyanin) extraction is also highlighted (Brianceau, Turk, Vitrac, \& Vorobiev, 2015). PEF application has a large potential for replacement or modification of the conventional thermal technology for sugar extraction from sugar beets. PEF pretreatment assisted "cold" extraction results in higher concentration of sucrose, lower concentration of colloidal impurities (especially, pectins), lower coloration and better filterability of juice (Loginova, Loginov, Vorobiev, \& Lebovka, 2011).

Traditionally, the increase of the yield in the juice and oil extraction industry has been one of the most important priorities. Gentle techniques that do not cause losses in nutritionally and organoleptic attributes should be used in the procedures to improve the extraction yield. Different plant based matrix was successfully studied for pressure expression combined with PEF pretreatments. Fruit juices (apple, grape...) and vegetable oils (olive) yield is significantly increased when moderate PEF treatments are applied before mechanical expression (Vorobiev \& Lebovka, 2015). The electric treatment does not induce bad flavors or taste in the oil (Abenoza et al., 2013) and can produce less turbid, significantly odorant and high polyphenols content apple juices (Turk, Vorobiev, \& Baron, 2012).

Pulsed Electric Field can also be combined with other mechanical separation operation such as filtration. The electric treatment helps reducing the solute-related resistance to the permeate flux for concentrating proteins. Significant improvements in the rate of concentrating the protein in the retentate can be obtained, resulting in reduced membrane surface area requirements for a specific degree of separation (Robinson et al., 1993).

The combination of PEF with extraction methods such as distillation is also a successive method that leads to an increase of essential oil yield 
Version définitive du manuscrit publiée dans / Final version of the manuscript published in :

Innovative Food Science and Emerging Technologies (2017), Vol. 41, p. 357-377,

DOI: 10.1016/j.ifset.2017.04.016, Journal homepage : http://www.elsevier.com/locate/ifset
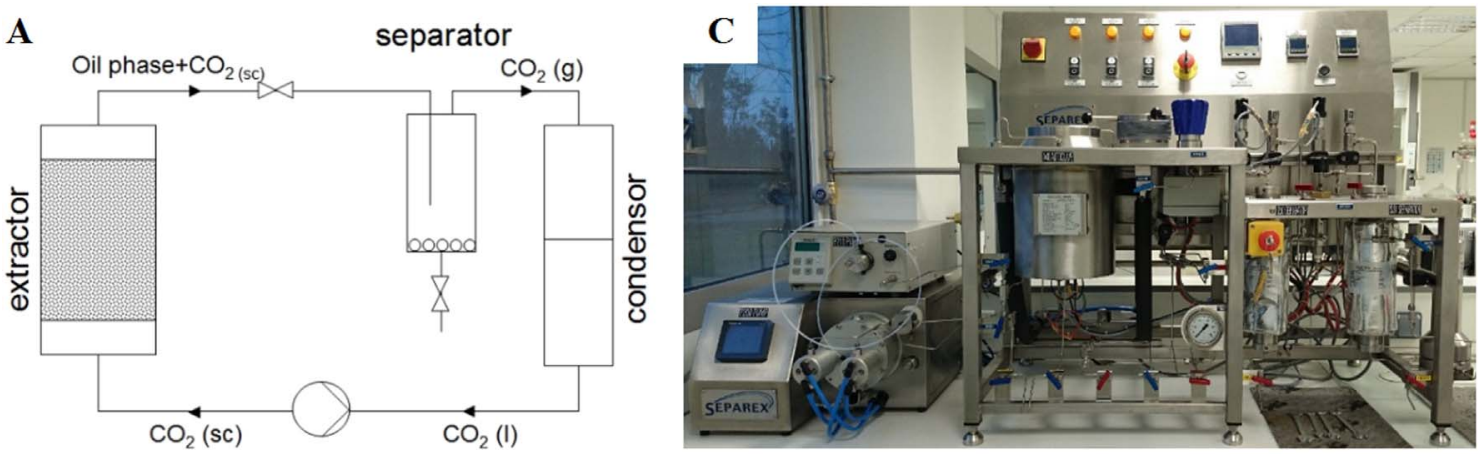

B

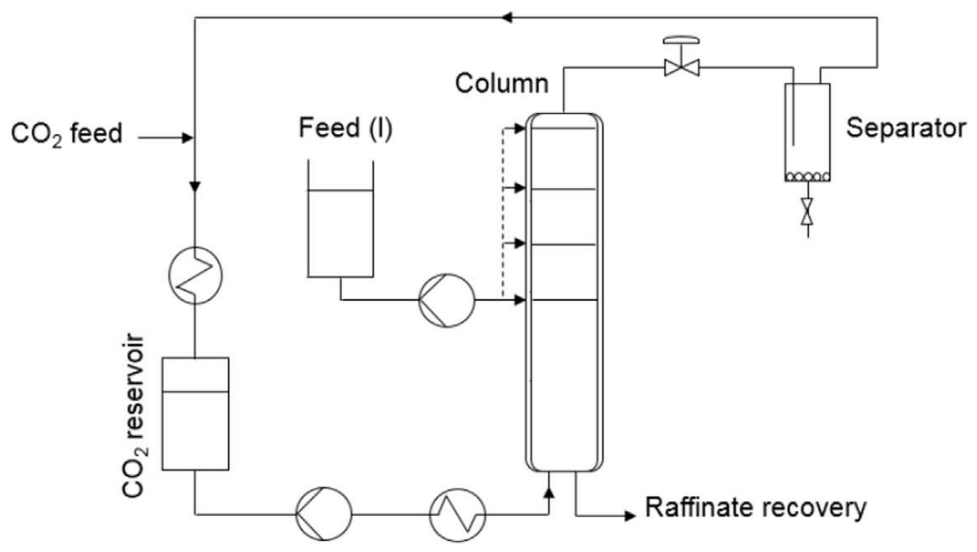

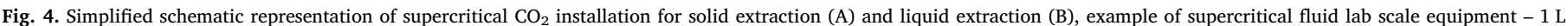
autoclave (C).

and reduces the distillation time (Dobreva, Tintchev, Heinz, Schulz, \& Toepfl, 2010).

\subsection{Transformation}

In addition to preservation and extraction applications, other methods were proposed to enhance transformation processes in the latest years. PEF is successfully applied to enhance the mechanical removal of undesired food parts. Skin removal of some fruits (tomato, mango...) gave results equal to steam peeling but with low applied energy (Toepfl, 2012). The data which are available on this topic are rather scarce.

Several studies have demonstrated interesting effects of PEF on softening vegetables and animal tissues. The viscoelastic and textures properties were changed after the electric treatment probably due to loss of turgor pressure (Lebovka, Praporscic, \& Vorobiev, 2004). These modifications have direct impact on decreasing the cutting force of fruits (Leong, Richter, Knorr, \& Oey, 2014) and improving meat tenderness (Bekhit, Suwandy, Carne, Van de Ven, \& Hopkins, 2016).

Several applications in preparation, curing and cooking of meat (McDonnell, Allen, Chardonnereau, Arimi, \& Lyng, 2014) and vegetable products have also been proposed (Toepfl, Siemer, \& Heinz, 2014). For instance, the application of moderate PEF treatment to potatoes improves its color and reduces oil uptake after frying (Ignat, Manzocco, Brunton, Nicoli, \& Lyng, 2015).

Low intensity PEF treatment, inducing reversible electroporation, was recently presented as stressing method to promote production of metabolites in vegetables or to accelerate biological reactions (Toepfl et al., 2006). Mattar et al. (2015) showed that the electric treatment prior to fermentation increases fructose consumption up to 3.98 times at the end of the lag phase and $20 \mathrm{~h}$ decrease of the overall fermentation time can be achieved compared to control (without electric treatment).

\subsection{Success stories}

The numbers of applications related to pulsed electric fields are constantly increasing. New ideas are being tested in laboratory and at industrial scale as reliable pulse modulators and tum-key systems. Recently, new PEF equipment manufacturers, such as Elea, Steribeam, Scandinova, and PurePulse, located in Germany, Sweden, and The Netherlands, respectively, have emerged, thus indicating the growing interest of the food industry in the application of the technology. A cooking device Nutri-Pulse ${ }^{\circledast}$ e-Cooker ${ }^{\circledast}$, commercialized by IXL Netherlands B.V. is advertised as capable of preparing food with help of electroporation and pulse ohmic heating, results in better conservation of the original nutritive value and the original flavor, color, structure and taste.

\section{Supercritical fluids}

\subsection{Principle, process and procedure}

\subsubsection{Principle}

Supercritical fluids (SCF) represent an alternative to organic solvents in processes using solvents (Badens, 2012). A fluid is considered to be in its critical state when it is both heated above its critical temperature (Tc) and pressurized above its critical pressure (Pc) (Brunner, 2005). The specificity of SCF relies in their physical properties, which can be modulated by an increase of pressure and/or temperature, beyond their critical values. SCF have a density close to liquids, which induces a solvating power close to liquids. Their viscosity, close to gases and a diffusivity that is intermediary between liquids and gases, leads to an increase of mass transfer between the solute to extract and the SCF. These properties enable adjustment of solvent selectivity of a SCF towards a target compound, which is particularly interesting in the case of extraction. 
Version définitive du manuscrit publiée dans / Final version of the manuscript published in :

Innovative Food Science and Emerging Technologies (2017), Vol. 41, p. 357-377,

DOI: 10.1016/j.ifset.2017.04.016, Journal homepage : http://www.elsevier.com/locate/ifset

Supercritical $\mathrm{CO}_{2}\left(\mathrm{SC}-\mathrm{CO}_{2}\right)$ is the fluid mostly used in SCF processes (Rozzi \& Singh, 2002). Process implementation is eased due to its low critical coordinates (Tc: $31^{\circ} \mathrm{C}$, Pc: $7.38 \mathrm{MPa}$ ). Moreover, some of its advantages include non-inflammability, cheapness, abundance and its volatility at atmospheric pressure implies that after depressurization extracts are solvent-free. $\mathrm{SC}-\mathrm{CO}_{2}$ is a non-polar solvent; its solvent power is comprised between the one of pentane and toluene (Lumia, 2011). To enhance solubilization of polar substances, a polar modifier (ethanol, methanol for example) can be added to $\mathrm{SC}-\mathrm{CO}_{2}$.

\subsubsection{Process implementation}

Concerning extraction and fractionation, two types of equipment settings can be found. Supercritical fluid extraction (SFE) from solid materials is achieved with autoclaves (industrial units may be composed of several autoclaves for semi-continuous processing). Liquid fractionation with SCF is performed with countercurrent columns (for continuous processing).

SCF extraction installations for solid processing are composed of four main parts: (i) a volumetric pump, to ensure a correct pumping of the fluid, the pump can be preceded by a cooler which brings gaseous component in a liquid state (ii) a heat exchanger, (iii) an extractor, where pressure is established and maintained by a back pressure regulating valve, (iv) a separator (Fig. $4 \mathrm{~A}$ and $\mathrm{C}$ ). Up to three separators can be put in series, to achieve multiple fractioning of the molecules contained in the extracts.

Extraction by SCF from solids is divided in two main steps: the extraction and the separation of the solute from the solvent. To perform SFE, the fluid has to be brought in its supercritical state. To achieve this, the fluid is usually sequentially pressurized and heated before entering the extractor. Brought at the desired pressure and temperature, the SCF percolate in the extractor, with an ascending or descending flux. The SCF extract the solute contained in the matrix. Separation of the solute from the SCF will be achieved in the separator, where the SCF will turn into a gaseous state, and the solute no longer solubilized in the SCF will be separated by gravity. Extracts are therefore collected at the bottom of the separator. Depending on the equipment, the gas can be recycled by being re-injected in the system, or released to atmosphere.

Fractioning from a liquid feed can be performed in batch mode, where extraction is performed by desorption of a liquid placed on an absorbent using the same equipment as for solid extraction (Benaissi, 2013). In a continuous mode, a countercurrent column is used to selectively recover a solute from the feed (Fig. 4B). Regarding process implementation, the feed is introduced in the middle or on the top of the column, the supercritical phase being introduced at the bottom of the column. The extract to be recovered and the fluid leave at the top of the column and the raffinate (heavier phase) is recovered at the bottom of the column. SCF preparation and regeneration are similar to SFE from solid material.

Apart from solid/fluid or fluid/fluid extraction processes, SCF are used for particle formation process and are the subject of extensive reviews (Jung \& Perrut, 2001; Reverchon, 1999; Reverchon \& Adami, 2006; Rodríguez-Meizoso \& Plaza, 2015). The general concept of two processes is briefly described below:

RESS (Rapid Expansion of a Supercritical Solution). The solute of interest is diluted in a supercritical phase and the resulting mixture is rapidly depressurized through a nozzle. This process has the advantage to produce very fine solid particles, but its applications are limited by the polarity of the solutes to precipitate (low polarity solutes).

GAS or SAS (Gas or Supercritical fluid Anti Solvent) which concept is to "decrease the solvent power of a polar liquid solvent in which the substrate is dissolved, by saturating it with carbon dioxide in supercritical conditions" (Jung \& Perrut, 2001). This causes the substrate to precipitate or to recrystallize.
Compared to conventional processes, several key advantages result from the use of SCF. Absence or limited solvent consumption (in the case of co-solvent use) leads to production of a solvent-free extract. The depressurization step in supercritical fluid processes (SFP) enables limiting the number of unit operations, since no separation or purification step is necessary. By operating at low temperatures during the whole process, SFP are adapted to production of heat-sensitive biomolecules. Additionally, SCP are intrinsically sterile (Badens, 2012).

\subsection{Applications in Green Food Processing}

Since the 1970s, a great number of applications using SCF have emerged and have been developed at laboratory and pilot scale. In this section, some applications from published studies related to food processing are reviewed, with a special emphasis on those dedicated to transformation, preservation and extraction by SCF. Far from being exhaustive, the examples given, when possible, will be supported by key related reference reviews or papers.

\subsubsection{Transformation}

Transformation processes can be achieved with the use of SCF, and most of them are related to particle formation processes. Precipitation or crystallization of food compounds can be achieved by SAS-type processes (e.g. carotenoids). To enhance biomolecules properties preservation, encapsulation with SCF has been investigated (Cocero, Martín, Mattea, \& Varona, 2009; Rodríguez-Meizoso \& Plaza, 2015). RESS and SAS processes have been successfully applied for anthocyanins and antioxidant encapsulation (Table 3). Process performances are generally evaluated according to particle characteristics (size and morphology), encapsulation efficiency and release of encapsulated compounds in a matrix.

Textural modifications of food matrix have been produced by combining extrusion and SCF (Maskan \& Altan, 2011; Rizvi, Mulvaney, \& Sokhey, 1995). By injecting SC- $\mathrm{CO}_{2}$ during the extrusion process, the processing conditions are milder than conventional extrusion (lower shear and starch expansion is possible below $100{ }^{\circ} \mathrm{C}$ ). Therefore, torque, equipment wear and heat-sensitive compound degradation can be minimized. Expansion of extrudates can be controlled according to the amount of $\mathrm{SC}-\mathrm{CO}_{2}$ injected, improving the structural characteristics of extrudates (Table 3).

Fractioning by SCF is used for aroma fractioning, where waxes (compounds of high molecular weight) can be separated from the volatile fraction or for lipid fractionation from oils (Reverchon, 1997). Fractioning can be performed after extraction in the depressurization stages through the separators or with a countercurrent column. Fractional extraction can also enable a selective recovery of compounds (Table 3, Palma, Taylor, Varela, Cutler, \& Cutler, 1999).

The use of SCF for micronization of particles for food applications has been described by Weidner (2009). Production of powdered food such as chocolate or lecithin at different particle size can be obtained through RESS, SAS and PGSS (Particle from Gas Saturated Solutions) (Weidner, 2009).

\subsubsection{Preservation}

Food preservation aims at conserving organoleptic properties and guarantees safety in food consumption. Food deterioration may be caused by several factors such as micro-organisms development and endogenous enzymatic activity. The use of SCF or high pressure gases for preservation by sterilization, for microbial, virus and spore inactivation has been the subject of some extended reviews (Garcia-Gonzalez et al., 2007; Perrut, 2012; Spilimbergo, Elvassore, \& Bertucco, 2002).

High hydrostatic pressure has been known to enable sterilization and pest control (Perrut, 2012), but the required pressure is quite high e.g. between 2 and 3000 bars (Spilimbergo et al., 2002). Requiring milder conditions for similar results, the use of SCF appears as a suitable alternative for food preservation. Early studies reported that relatively 


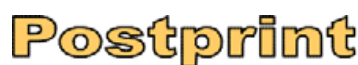

Version définitive du manuscrit publiée dans / Final version of the manuscript published in :

Innovative Food Science and Emerging Technologies (2017), Vol. 41, p. 357-377,

DOI: 10.1016/j.ifset.2017.04.016, Journal homepage : http://www.elsevier.com/locate/ifset
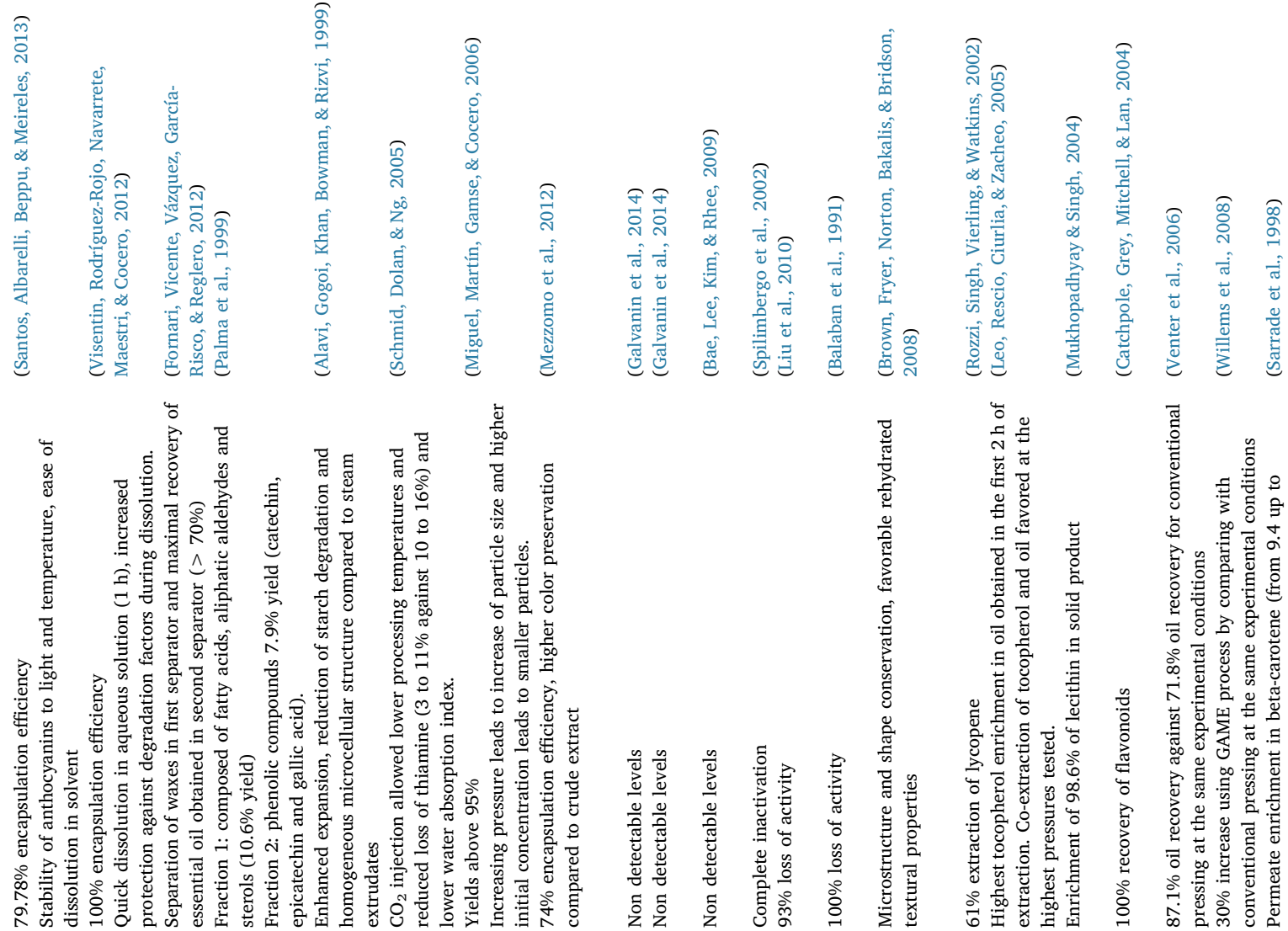

要

$\begin{array}{lll} & \\ 0 & & \\ 0\end{array}$

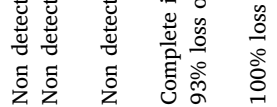

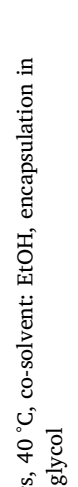

若歌

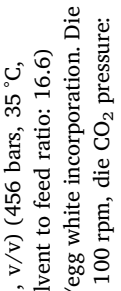

छัญ సิ

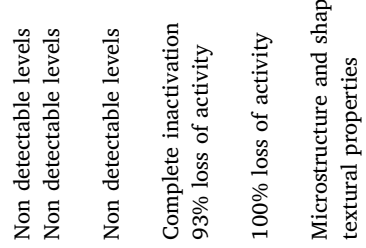

ฮี

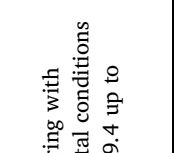

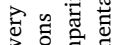

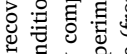

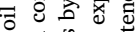

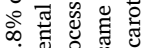

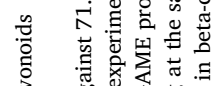

(o)

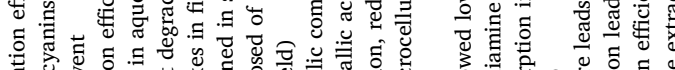

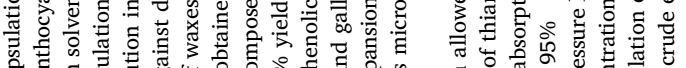

空 示.

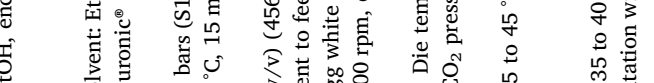

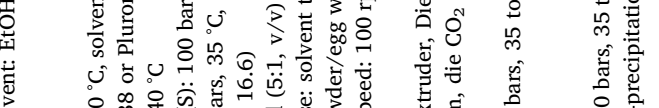

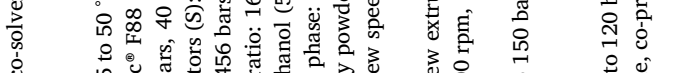

U.

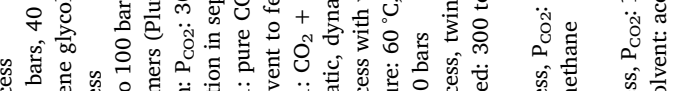

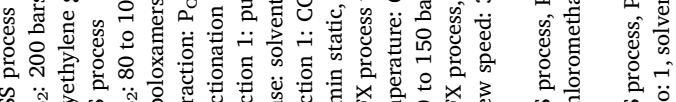

(a)

节

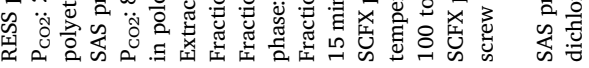

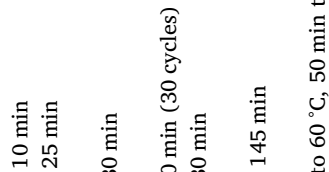

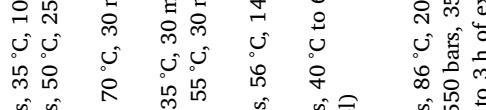

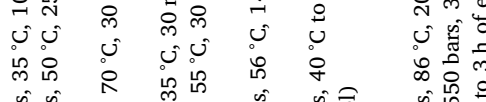

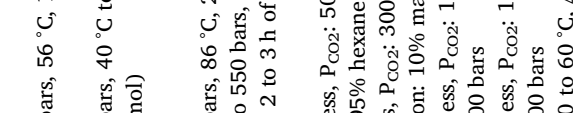

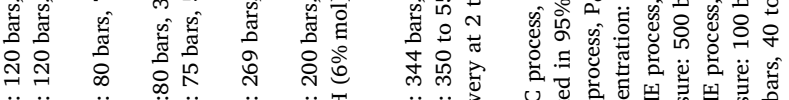

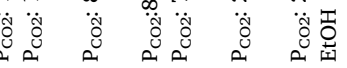

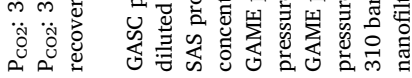

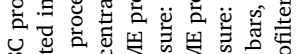

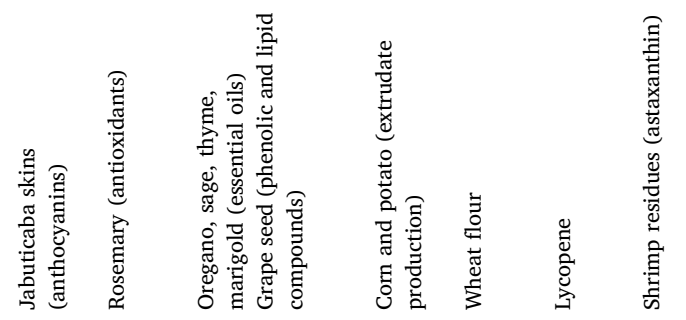

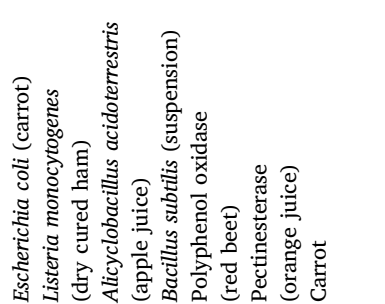

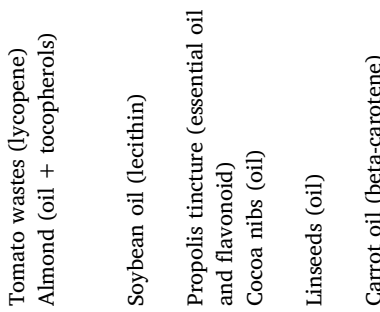

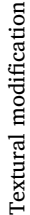

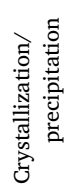

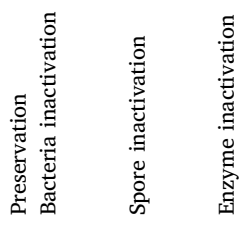

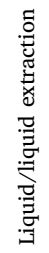


Version définitive du manuscrit publiée dans / Final version of the manuscript published in :

Innovative Food Science and Emerging Technologies (2017), Vol. 41, p. 357-377,

DOI: 10.1016/j.ifset.2017.04.016, Journal homepage : http://www.elsevier.com/locate/ifset

mild conditions were sufficient to inhibit the growth and increase the inactivation rate (heat treatment of 50 to $55^{\circ} \mathrm{C}$ with 6 bars of $\mathrm{CO}_{2}$ ) (Fraser, 1951; Perrut, 2012). Generally, the microbial inactivation is greatly affected by pressure, temperature, exposure duration and compression/decompression cycles (Garcia-Gonzalez et al., 2007; Melo Silva et al., 2013; Perrut, 2012; Spilimbergo et al., 2002). The presence of water is reported to increase the bactericidal effect of $\mathrm{CO}_{2}$, most probably due to its relationship with $\mathrm{pH}$, where acidic $\mathrm{pH}$ tends to favor inactivation (Garcia-Gonzalez et al., 2007; Garcia-Gonzalez et al., 2009). Some other authors investigated the positive effect of condensed gases (e.g. $\mathrm{CO}_{2}, \mathrm{~N}_{2}$ ) on microorganisms inactivation. However, it must be underlined that the matrix effect plays a major role during the inactivation process (Garcia-Gonzalez et al., 2007; Wei, Balaban, Fernando, \& Peplow, 1991). Recent investigations on food matrices (Table 3) report that inactivation can be obtained with moderate conditions $\left(\mathrm{CO}_{2}\right.$ pressure between 80 and 120 bars and below $\left.70{ }^{\circ} \mathrm{C}\right)$. Such conditions enable a complete inactivation or no detectable levels in foods such as carrots, cured ham, apple and orange juice and red beet after treatment.

Enzyme inactivation can be obtained when exposed to $\mathrm{SC}-\mathrm{CO}_{2}$ conditions or dense phase conditions. Reported factors leading to enzyme inactivation are $\mathrm{pH}$ lowering and inhibitory effect of molecular $\mathrm{CO}_{2}$. In that sense, although inactivation can be achieved with others gases, $\mathrm{CO}_{2}$ is suggested to have a unique role in inactivation (Damar \& Balaban, 2006). At very mild conditions (between 1 and 100 bars at temperatures below $60^{\circ} \mathrm{C}$ ), inactivation of enzymes such as pectin esterase and polyphenol oxidase can be achieved (Damar \& Balaban, 2006). It was noted that some enzymes such as lipoxygenase and peroxidase in sucrose solutions required higher pressures for inactivation (100 to 600 bars, below $55^{\circ} \mathrm{C}$ ) so some enzymes are more pressure-sensitive than others (Hendrickx, Ludikhuyze, Van den Broeck, \& Weemaes, 1998; Tedjo, Eshtiaghi, \& Knorr, 2000). Early studies report the use of $\mathrm{CO}_{2}$ microbubbles in batch and continuous systems for enzyme inactivation in liquid materials such as fruit juices (Ishikawa, Shimoda, Shiratsuchi, \& Osajima, 1995; Ishikawa et al., 1997; Wimmer \& Zarevúcka, 2010).

\subsubsection{Extraction}

Extraction by SCF is well-known at both academic and industrial level and therefore is the subject of numerous publications. Four types of processes related to extraction are presented in Table 3.

Supercritical extraction of natural products (such as oils and fats, antioxidants, pigments and aromas) by percolation is described in several reviews (Díaz-Reinoso, Moure, Domínguez, \& Parajó, 2006; Herrero, Cifuentes, \& Ibañez, 2006; Reverchon, 1997; Reverchon \& De Marco, 2006). From literature survey, it can be identified that usually high pressures are required (above 280 bars) for extraction of high molecular weight compounds such as oils. Aromatic fractions such as essential oils are extracted using moderate conditions (pressures from 70 to 200 bars and temperatures from 40 to $60{ }^{\circ} \mathrm{C}$ ) (Reverchon, 1997; Sovová, Aleksovsk, Bocevska, \& Stateva, 2006). Focus in extraction by percolation is also set on by-product valorization or on the use of SCF for co-extraction of compounds for enhancement of final product attributes (Table 3). Liquid-liquid extraction is applied for numerous applications such as concentrated aromas production from beverages and alcohol removal (Brunner, 2005; Macedo et al., 2008), oil fractionation and deodorization (Shimoda et al., 2000; Torres, Torrelo, Señoráns, \& Reglero, 2009), and hexane removal from vegetable oils (Eller, Taylor, \& Curren, 2004). Processing pressures rarely exceed 300 bars.

Combined processes with SCF have been investigated to increase extraction performances. A process combining pressing and use of gases in a supercritical state (Gas Assisted Mechanical Expression, GAME) has been recently investigated to increase oil extraction yield (Voges, Eggers, \& Pietsch, 2008). This process has been successfully applied on various seeds (cocoa, linseeds, sesame, Table 3). Authors have noticed that pressing was greatly favored by SCF or dense gases, indeed a low mechanical pressure is necessary (around $10 \mathrm{MPa}$ ) to increase oil yield from 10 to $20 \%$ (all other conditions equal) (Venter, Willems, Kuipers, \& Haan, 2006; Willems, Kuipers, \& de Haan, 2008). Nanofiltration coupled to $\mathrm{SC}-\mathrm{CO}_{2}$ extraction for the purification of low molecular weight compounds $\left(1500 \mathrm{~g} \cdot \mathrm{mol}^{-1}\right)$ was introduced by Sarrade, Rios, and Carlès (1998). This process has been applied to purification of beta-carotene from carrot oil and to fractionation of fish oil triglycerides. Further developments on combination of membrane technologies and SCF are still on going in the field of edible oil refining (Temelli, 2009).

\subsection{Success story in the use of supercritical fluids: industrial production}

Industrial processing with SCF has been a reality for several years. Since early patents on coffee decaffeination or hops extraction in the 1970 's, a great number of industrial units have emerged. In 2009, Perrut estimated that 300 industrial units were using SCF. For supercritical extraction performed on solid materials, the main applications are related to food and perfume industry: aromas and flavors extraction (hops, vanilla, ginger, roses...), coffee and tea decaffeination. For example, Maxwell House Coffee (a division from General Foods) has reported processing 80,000 tons of coffee per year. The plant is equipped with a $60 \mathrm{~m}^{3}$ extractor and to function in a semi-continuous scale (Benaissi, 2013). The removed caffeine is further sold to pharmaceutic or food companies.

\section{Microwave extraction}

\subsection{Process and procedure}

Microwave heating results from the dissipation of the electromagnetic waves in the irradiated medium. The dissipated power in a medium depends on the dielectric properties and the local timeaveraged electric field strength. So, there is a fundamental difference between microwave and conventional heating: in conventional heating, heat transfers occur from the heating device to the medium, whereas in microwave heating, heat is dissipated inside the irradiated medium. In contrast with conventional heating, microwave heat transfer is not limited to thermal conduction or convection currents (Fig. 5). In practice, this means that a much faster temperature increase can be obtained. Furthermore, the maximum temperature of the material heated by microwaves is only dependent upon the rate of heat loss and power applied.

Although microwaves create volumetric heating, the field distribution is not even throughout the irradiated material. Therefore, the energy is not homogeneously dissipated. The electric field distribution depends on the geometry of the heated object and the dielectric properties. For media which readily absorb microwaves, the depth at which power density is reduced to 1 /e of original intensity might be a limiting factor.

For more transparent media, the occurrence of standing wave patterns will result in 'hot spots' if the power dissipation is faster than the heat transfers to surrounding colder areas. As a general rule a standing wave pattern can occur if multiples of a half wavelength fit in the typical dimension (d) of the irradiated object.

Microwave ovens can have monomode or multimode cavity. The monomode cavity can generate a frequency which excites only one mode of resonance. Their use for food processing is limited because the volume has to be extremely small in order to maintain the resonance. The majority of food heating applications (Edgar \& Osepchuk, 2001) use a multimode resonance cavity applicator because it permits large volumes. The incident wave is able to affect several modes of resonance, and this superimposition of modes allows the homogenization of field. 
Version définitive du manuscrit publiée dans / Final version of the manuscript published in :

Innovative Food Science and Emerging Technologies (2017), Vol. 41, p. 357-377,

DOI: 10.1016/j.ifset.2017.04.016, Journal homepage : http://www.elsevier.com/locate/ifset
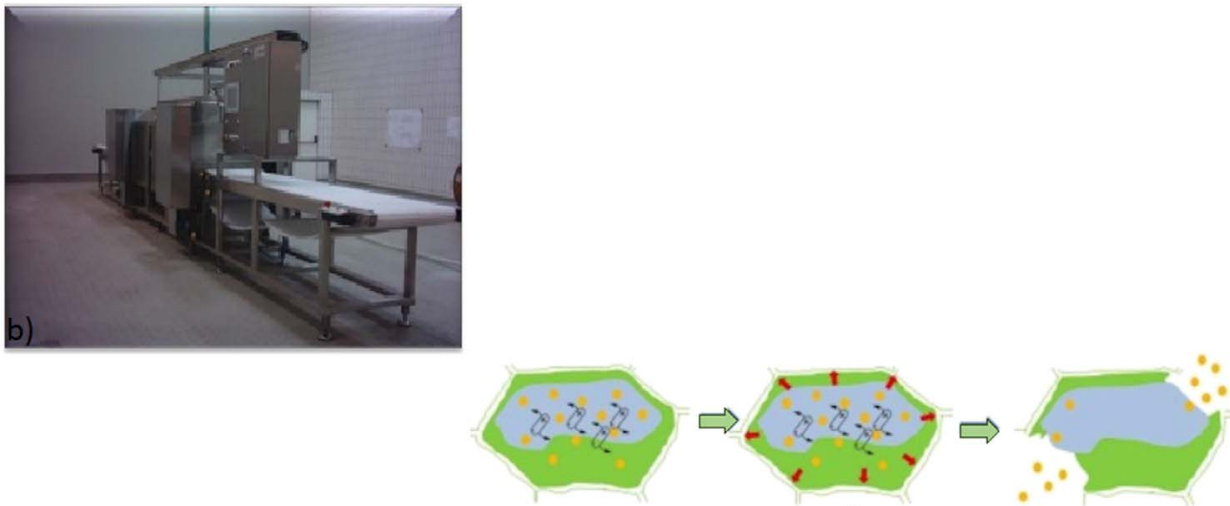

a)
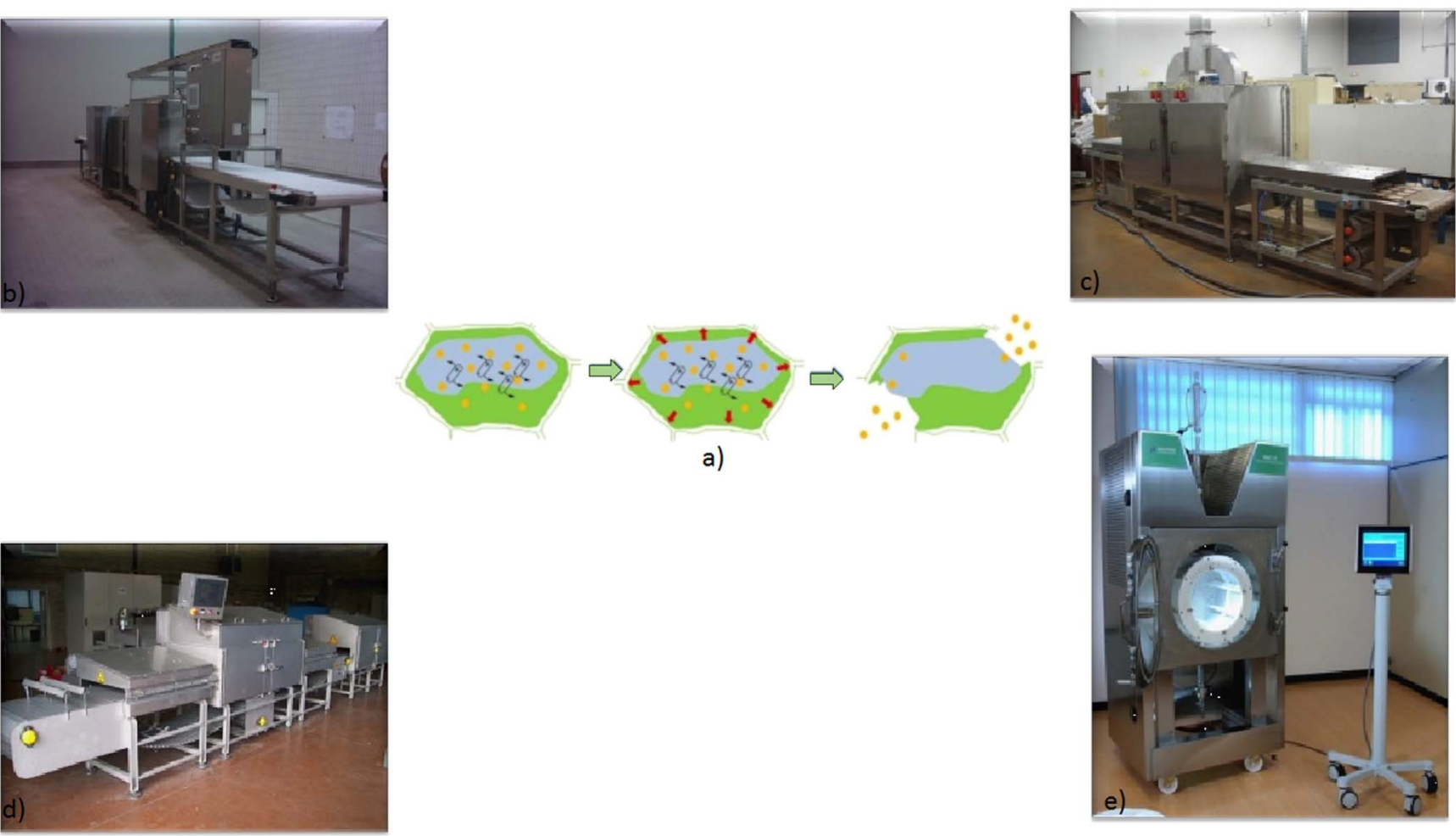

g. 5. (a) A brief description of phenomenon in the cell generated by microwave irradiation, (b) microwave tunnel to temper, reproduced with permission from SAIREM, (c) microwave

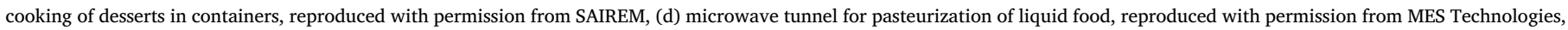
(e) microwave extraction: SFME and MHG, reproduced with permission from Millestone.

Microwaves are only absorbed by dipoles, transforming their energy into heat. Heat transfer advantages of applying microwave power, a non-contact energy source, into the bulk of a material include: faster energy absorption, reduced thermal gradients, selective heating and virtually unlimited final temperature. Several processes such as drying, tempering, thawing, blanching, sterilization, pasteurization, baking and

Table 4

Example of applications and experimental conditions of MW.

\begin{tabular}{|c|c|c|c|c|}
\hline Application & Matrix & Treatment conditions & Benefits & Reference \\
\hline \multicolumn{5}{|l|}{ Preservation } \\
\hline Pasteurization & Kiwifruit puree & $\begin{array}{l}\text { P: } 1000 \mathrm{~W}, \mathrm{t}: 200 \mathrm{~s} \text { and } \mathrm{P}: 900 \mathrm{~W}, \mathrm{t}: \\
225 \mathrm{~s} ; \mathrm{m}: 500 \mathrm{~g}\end{array}$ & Inactivation $90 \%$ of peroxidase enzyme & $\begin{array}{l}\text { Benlloch-Tinoco, Martínez- } \\
\text { Navarrete, \& Rodrigo, } 2014\end{array}$ \\
\hline Thawing & Strawberries & $\mathrm{P}: 700 \mathrm{~W}, \mathrm{t}: 10 \mathrm{~min}, \mathrm{~m}: 250 \mathrm{~g}$ & $\begin{array}{l}\text { A reduction in processing time, } \\
\text { No influence on the quality indices (color, ascorbic } \\
\text { acid and anthocyanins contents) }\end{array}$ & $\begin{array}{l}\text { Holzwarth, Korhummel, } \\
\text { Carle, \& Kammerer, } 2012\end{array}$ \\
\hline Sterilization & Palm fruit & $\mathrm{P}: 800 \mathrm{~W}, \mathrm{t}: 2 \mathrm{~min}$ & $\begin{array}{l}\text { Increment in lauric acid (C12: } 0 \text { ), } \\
\text { Highest concentration of vitamin E and carotene } \\
\text { content, } \\
\text { Clean technology due to zero water effluent discharge }\end{array}$ & Cheng, Mohd Nor, \& Chuah, 2011 \\
\hline \multicolumn{5}{|l|}{ Extraction } \\
\hline MHG & $\begin{array}{l}\text { Grape juice by- } \\
\text { products }\end{array}$ & P: $400 \mathrm{~W}$, t: $20 \mathrm{~min}, \mathrm{~m}: 400 \mathrm{~g}$ & $\begin{array}{l}\text { Green extraction method, } \\
\text { Efficiency of MHG in the extraction of polyphenols and } \\
\text { anthocyanins from grape by-products }\end{array}$ & $\begin{array}{l}\text { Al Bittar, Périno-Issartier, } \\
\text { Dangles, \& Chemat, } 2013\end{array}$ \\
\hline SFME & Lavender flowers & $\mathrm{P}: 500 \mathrm{~W}, \mathrm{t}: 10 \mathrm{~min}$ & $\begin{array}{l}\text { Extraction of essential oils } \\
\text { Short extraction time }\end{array}$ & Chemat et al., 2006 \\
\hline MHG & $\begin{array}{l}\text { Rosmarinus } \\
\text { officinalis L. }\end{array}$ & $\mathrm{P}: 500 \mathrm{~W}, \mathrm{t}: 15 \mathrm{~min}$ & $\begin{array}{l}\text { Extraction of antioxidants } \\
\text { Economy in term of time and energy } \\
\text { More safer extraction }\end{array}$ & $\begin{array}{l}\text { Abert Vian, Fernandez, } \\
\text { Visioni, \& Chemat, } 2008\end{array}$ \\
\hline \multicolumn{5}{|l|}{ Transformation } \\
\hline Drying & bananas & $\begin{array}{l}\text { P: } 400 \mathrm{~W} \text {, magnetron is « on » for } \\
11 \mathrm{~s} \text { and « off» for } 18 \mathrm{~s}, \mathrm{~m}: 86 \mathrm{~g} .\end{array}$ & $\begin{array}{l}\text { Creation dried-and-crisp fruits by applying successive } \\
\text { cycles of heating and vacuum pulses in a microwave } \\
\text { field }\end{array}$ & Monteiro, Carciofi, \& Laurindo, 2016 \\
\hline Baking & Cake batter & $\begin{array}{l}\text { P: } 250 \mathrm{~W}, \mathrm{t}: 67 \mathrm{~s}, \mathrm{~m}: 30 \mathrm{~g} \text { of freshly } \\
\text { prepared batter }\end{array}$ & $\begin{array}{l}\text { 93\% reduction in baking time/convective baking } \\
\text { Improvement textural properties such as moisture } \\
\text { content and firmness } \\
\text { Highest nutritive value }\end{array}$ & Megahey et al., 2005 \\
\hline Blanching & Brussels sprouts & $\begin{array}{l}\mathrm{P}: 700 \mathrm{~W}, \mathrm{t}: 5 \mathrm{~min} \text { followed by } \\
\text { blanching in boiling water for } \\
2 \mathrm{~min} .\end{array}$ & $\begin{array}{l}\text { No deleterious effects on total flavonoids and ascorbic } \\
\text { acid, } \\
\text { Improvement health properties of Brussels sprouts }\end{array}$ & Vina et al., 2007 \\
\hline
\end{tabular}


Innovative Food Science and Emerging Technologies (2017), Vol. 41, p. 357-377,

DOI: 10.1016/j.ifset.2017.04.016, Journal homepage : http://www.elsevier.com/locate/ifset

extraction have been applied efficiently in the food industry.

\subsection{Applications in food processing (Table 4)}

Drying is one of the oldest methods of preserving food and can be specified as a simultaneous heat and mass transfer operation in which water activity of a foodstuff is lowered by the removal of water by evaporation into an unsaturated gas stream. The most important characteristic of microwave dehydration is volumetric heating effect where the microwave energy travels through the food and is absorbed more in the wet region than in the dry region of the product. Consequently, the centre is warmer than the surroundings and the mass transfer is accelerated. Microwave drying results in a high thermal efficiency, shorter drying time and improves the final quality of the dried product compared to conventional drying. MW drying is also able to maintain good quality of the product such as color, aroma and texture (Fathima, Begum, \& Rajalaksmi, 2001).

Several experimenters have reported microwave-assisted hot-air drying experiments with foodstuffs, where considerable improvements in the drying process have been evident such as better aroma, faster, and better rehydration (Gowen, Abu-Ghannam, Frias, \& Oliveira, 2006) than hot-air drying.

Quality can often be improved further by the addition of vacuum: Vacuum Microwave Drying (VMD) offers an alternative way to retain volatile compounds sensitive to losses through thermal and oxidative degradation. Moreover, the absence of air during drying reduces oxidation and therefore, color, texture and nutrient content of products are all improved (Gunasekaran, 1999). The VMD technique was also successfully applied to cranberries, (Yongsawatdigul \& Gunasekaran, 1996) model fruits gels (Drouzas, Tsami, \& Saravacos, 1999), garlic (Cui, Xu, \& Sun, 2003), cabbages (Yangyang, Mujumdar, Le-qun, \& Jincai, 2004) and button mushrooms (Giri \& Prasad, 2006).

In addition to hot air, microwaves can also be combined with freeze drying. Freeze drying is used for heat sensitive product and almost no oxygen is involved in the process. However, this technique is costly, time and energy consuming. In this system, the energy is directly absorbed by the water molecules for sublimation within the material and increases the drying rate in freeze drying.

Blanching is a thermal treatment prior to freezing with the aim of inactivation of enzymes such as polyphenoloxidase (PPO) and peroxidase (POD) that are responsible for browning reactions and lead to offflavor development. Blanching also destroys microorganisms on the product surface and makes some vegetables more compact. Microwave blanching could be an alternative to conventional blanching, with precise process control, shorter processing time and less energy use and decreases the blanching time of the product centre. Many studies concluded that the microwave technique leads to firmer products, equal or better nutrient contents and similar colors when compared to conventional processing (Brewer \& Begum, 2003; Lin \& Brewer, 2005).

Tempering can be considered as the initial phase of the complete thawing process. Thawing of frozen foods is an important unit operation in the food industry. Large quantities of food have to be preserved by freezing at harvest time for use throughout the year. In microwave thawing, electromagnetic waves are directly absorbed by the product without the use of conductors or electrodes. Therefore, it is a very fast thawing method but its application is limited by product thermal stability. The problem is complex because the water loss factor is approximately 12 whereas that of ice is 0.003 , which means that the ice is almost insensitive to microwave energy. In a frozen product $\left(-18^{\circ} \mathrm{C}\right)$, unfrozen water preferentially absorbs the microwave energy whereas the frozen part is insensitive to microwaves. This leads to localized areas of very hot water, partial thawing and thermal runaway (Schiffmann, 2001). Improvements to maintain a uniform temperature during microwave thawing are necessary.

The advantage of microwave thawing was the reduction in processing time, even when there was no significant effect on product quality.
In the food industry, microwave ovens are often part of continuous processes. Thin layers of product circulate on a conveyor under a succession of microwave generators. Microwaves are used to thaw fish fillets and meat blocks.

Microwave tempering reduces costs of manufacturing prepared foods as frozen raw materials can be tempered as needed, with no drip loss, without the need for tempering rooms and reduced processing time.

Baking is a complex process, described as a simultaneous heat and mass transfer. Baking involves a series of physical, chemical and biochemical changes in food, such as starch gelatinization, protein denaturation, carbon dioxide liberation from leavening agents, volume increase, water evaporation, crust formation and non-enzymatic browning (Therdthai \& Zhou, 2003).

Microwave baking reduces the baking time and energy (Sumnu, 2001). Megahey, Mcminn, and Magee (2005) illustrated this by comparing the time to bake a cake by microwave and conventional baking. Microwave baking allowed for up to a $93 \%$ reduction in baking time, relative to convective baking. Cakes baked by microwaves showed improved textural properties such as moisture content and firmness. Another advantage of microwave baking is that the final product has a higher nutritive value.

Pasteurization is a thermal inactivation of pathogenic microorganisms, notably vegetative cells, yeasts and moulds. Sterilization is the inactivation of microorganisms and their spores, which are generally more thermo-resistant than vegetative cells. The microwave heating of food provides an excellent opportunity to pasteurize or sterilize the products. Products such as sweet mash potato (Coronel, Truong, Simunovic, Sandeep, \& Cartwright, 2005; Steed et al., 2008), a biphasic food product (salsa con queso) (Kumar, Coronel, Simunovic, \& Sandeep, 2007), green beans and mash carrot (Kumar et al., 2008), were treated and the feasibility of microwave sterilization was confirmed. The continuous pasteurization and sterilization of liquids with microwave equipment are a useful alternative processing approach but the price and the energy consumption are relatively high.

\subsubsection{Extraction}

Use of microwave energy was described for the first time in 1986 by Ganzler (Ganzler, Salgo, \& Valko, 1986) and Lane (Lane \& Jenkins, 1984) for extraction of food ingredients. In the last decade there has been an increasing demand for new extraction techniques, amenable to automation, with shortened extraction times and reduced organic solvent consumption, to prevent pollution and reduce the cost of sample preparation. Driven by these goals, advances in microwave green extraction have given rise to two classes of techniques: Solvent Free Microwave Hydrodistillation and Microwave Hydrodiffusion and Gravity.

Solvent Free Microwave Hydrodistillation (SFME) was conceived for laboratory scale applications in the extraction of essential oils from different kinds of aromatic plants and fruits (Chemat, Lucchesi, and Smadja (2004a, 2004b)) SFME apparatus is an original combination of microwave heating and distillation at atmospheric pressure. Based on a relatively simple principle, this method involves placing plant material in a microwave reactor, without any added organic solvent or water. The internal heating of the in situ water within the plant material distends the plant cells and leads to rupture of the glands and oleiferous receptacles. Thus, this process frees essential oil which is evaporated by the in situ water of the plant material. A cooling system outside the microwave oven condenses the distillate continuously. The water excess is refluxed to the extraction vessel in order to restore the in situ water to the plant material. Therefore, the SFME method offers a reduced environmental burden as it rejects less $\mathrm{CO}_{2}$ in atmosphere $\left(200 \mathrm{~g} \mathrm{CO}_{2}\right.$ per gram of essential oil compared to traditional method which was rejecting $3600 \mathrm{~g} \mathrm{CO}_{2}$ per gram of essential oil) (Chemat et al., 2004a, 2004b; Ferhat, Meklati, Smadja, \& Chemat, 2006).

Microwave Hydrodiffusion and Gravity (MHG) extraction was 
Innovative Food Science and Emerging Technologies (2017), Vol. 41, p. 357-377, DOI: 10.1016/j.ifset.2017.04.016, Journal homepage : http://www.elsevier.com/locate/ifset

patented by Chemat et al., 2008. This green extraction technique is an original "upside down" microwave alembic combining microwave heating and earth gravity at atmospheric pressure. MHG was conceived for laboratory and industrial scale applications for the extraction of food ingredients from different kind of fruits, vegetables and aromatic plants. This method involves placing plant material in a reactor inside the microwave oven, without adding any solvent or water. Microwaves induce warming of the water contained in the matrix, which allows the destruction of cells containing essential oil. Essential oils, as well as the internal water of the matrix, are released and transferred from inside to the outside of the plant: this is the hydrodiffusion phenomenon. A cooling system placed outside the microwave oven allows the condensation of the distillate. It is important to note that this green method allows extract of essential oils without distillation and evaporation which are the most energy consuming processes between the unit operations (Périno-Issartier, Giniès, Cravotto, \& Chemat, 2013).

\subsection{Success story}

Using microwaves, full reproducible food processes can now be completed in seconds or minutes with high reproducibility, reducing the processing cost, simplifying manipulation and work-up, giving higher purity of the final product, eliminating post-treatment of waste water and consuming only a fraction of the time and energy normally needed for a conventional processes heated by convection, conduction, or radiation. For food production, the resultant value could include: more effective heating, fast heating of packaged food, reduced equipment size, faster response to process heating control, faster start-up, increased production, and elimination of process steps.

\section{Ultrasound assisted food processing}

Ultrasound is a sound frequency in the range between 18 and $100 \mathrm{kHz}$ that is above hearing of the human ear. High power ultrasound means application of intensities higher than $1 \mathrm{~W} \cdot \mathrm{cm}^{-2}$ (usually in the range between 10 and $1000 \mathrm{~W} \cdot \mathrm{cm}^{-2}$ ). High power and low frequency ultrasound ( $\mathrm{f}=20$ to $100 \mathrm{kHz}$ ) is considered as "power ultrasound" because its application causes cavitation and is applied in the food industry (Paniwnyk, 2005). The benefits of US are attributed to acoustic cavitation: micro-bubbles created in a liquid phase when subjecting a mixture to US will grow and oscillate quickly before collapsing due to pressure changes (Chemat et al., 2008; Jambrak, Mason, Lelas, Herceg, \& Herceg, 2008) (Fig. 6a). These violent implosions will fragment or disrupt the surface of the solid matrix, enhancing mass transfer and accelerating diffusion.

The effectiveness of the ultrasound depends to the acoustic frequency, temperature and pressure applied. Lower frequencies generate larger bubbles and thus a more violent bubble collapse with higher localized temperatures and pressures. However, as frequency is increased, there are more collapse events per unit time. Two different types of ultrasound equipment are commonly used in laboratory (Fig. 6). The first one is the ultrasonic cleaning bath (Fig. 6b) which is commonly used for solid dispersion into solvent (ultrasounds will dramatically reduce the size of the solid particles, which will enhance its solubility), for degassing solutions or even for cleaning small material by immersion of the glassware into the bath. The ultrasonic baths are less used for chemical reactions even if they are easy to handle and economically advantageous because reproducibility of reaction is low. In fact, the delivered intensity is low and is highly attenuated by the water contained in the bath and the walls of the glassware used for the experiment. The second one, the ultrasonic probe or horn system (Fig. 6d), is much more powerful because the ultrasonic intensity is delivered on a small surface (only the tip of the probe) compared to the ultrasonic bath. Another change is that the probe is directly immersed into the reaction flask so less attenuation can happen. This system of probe is widely used for sonication of small volumes of sample but special care has to be taken because of the fast rise of the temperature into the sample. A special sono-extraction reactor (from 0.5 to $3 \mathrm{~L}$ ) has been developed by REUS (www.etsreus.com, FRANCE) (Fig. 6c) The intensity of ultrasounds is about $1 \mathrm{~W} / \mathrm{cm}^{2}$ with a frequency of $25 \mathrm{kHz}$. In order to keep constant temperature, the reactor is made of a double mantle into which cooling water can circulate. The main advantage of this type of apparatus is that the natural products and the extraction solvent are mixed into a container and the ultrasounds are directly applied to the mixture. To run out industrial trials or to scale-up laboratory experiments, REUS has also developed reactors from 30 to 1000 L (Fig. 6f, g). Pump systems are coupled to the ultrasonic bath in order to fill the ultrasonic bath, to stir the mixture and to empty the system at the end of the experiment. The manufacturers of high-power ultrasound equipment have been also focusing on designing devices by including specific operational features such as continuous flow mode. The equipment basically consists of a glass tube or stainless steel reactor, through which the fluid mixture is pumped, surrounded by a jacket filled with pressurized water for conduction of the sound waves. Ultrasound is transmitted to the system by a sonotrode attached to the jacket (Fig. 6e).

\subsection{Application in food processing}

There are a large number of potential applications of high intensity ultrasound in food processing of which a number are discussed below (Table 5).

\subsubsection{Degassing/deaeration}

A liquid contains gases as a mixed condition, such as dissolved oxygen, carbon dioxide, nitrogen gas etc. Two common methods used for degassing are boiling and reducing pressure while ultrasound has an advantage in the small temperature change. Degassing in an ultrasonic field is a highly visible phenomenon when ultrasound, e.g. an ultrasonic cleaning bath, is used with regular tap-water inside. It occurs when the rapid vibration of gas bubbles brought them together by acoustic waves and bubbles grow to a size sufficiently large to allow them to rise up through the liquid, against gravity, until they reach the surface (Laborde, Bouyer, Caltagirone, \& Gerard, 1998; Tervo, Mettin, \& Lauterborn, 2006). Several acoustic cavitation structures generated in low-frequency ultrasound fields within the range $(20-50 \mathrm{kHz})$ have been investigated and these have been summarized by Mettin (2005). In the food industry, this technique can be used to degas carbonated beverages such as beer (defobbing) before bottling (Brown \& Goodman, 1965).

\subsubsection{Demouling}

Generally, the industrial cooking of foods leads to adhesion of the products to the cooking vessel or in other operations it must detach from its mould. At present, to solve this problem mechanical methods such as knocking vibration are used to remove the products. An alternative solution to these conventional methods is to release food products by coupling the mould to a source of ultrasound (Scotto, 1988). The device for demoulding industrial food products couples the mould and the ultrasonic source in order to enhance removal of the product contained in the latter by virtue of the high-frequency relative movement between the contact surfaces of the mould and of the product contained in the latter. This technique allows surface coatings to be eliminated and ensures that any residual material in the mould can be cleaned automatically.

\subsubsection{Cutting}

The introduction of ultrasound in food cutting has improved the performance of overall food processing. Ultrasonic food cutting equipment provides a new way to cut or slice a variety of food products that streamlines production, minimizes product waste and lowers maintenance costs. Ultrasonic cutting uses a knife-type blade attached through 


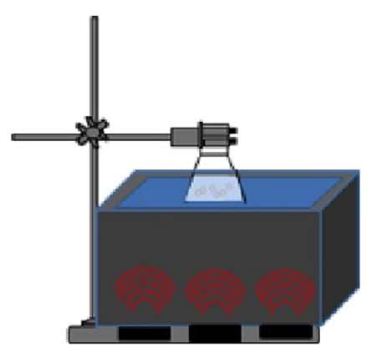

b)

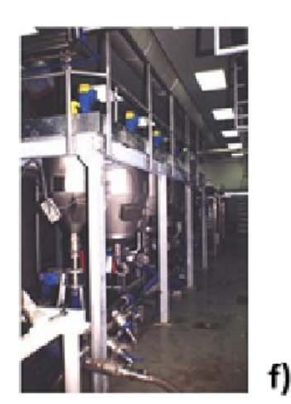

f)

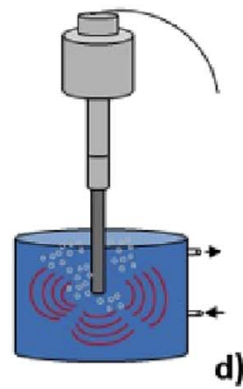

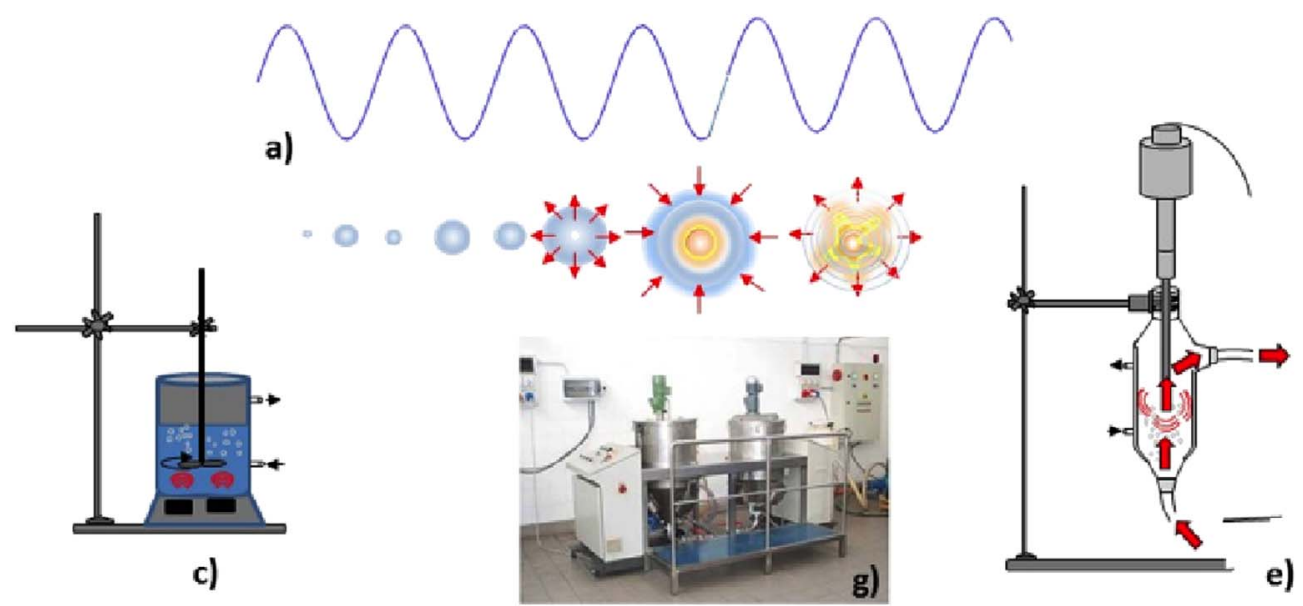

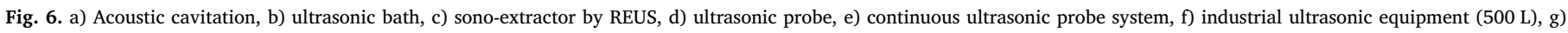
industrial ultrasonic equipment $(50 \mathrm{~L})$.

a shaft to an ultrasonic source (Rawson, 1988). The cutting tool itself can be of many shapes and each shape can be considered to be an acoustic horn, part of the whole ultrasonic resonating device. Cutting with the superimposition of ultrasonic vibration is a direct competitor of technologies such as high-velocity water jet cutting and conventional techniques such as using saws or knives. The low energy requirements for ultrasonic cutting have been presented (Schneider, Zahn, \& Rohm, 2008; Schneider, Zahn, Schindler, \& Rohm, 2009). The ultrasonic cutting characteristics depend on the food type and condition, e.g. frozen or thawed (Brown, James, \& Purnell, 2005). The most widespread application of ultrasound is in the cutting of fragile foodstuffs. It uses in the particular cases of fragile and heterogeneous products (cakes, pastry and bakery products) and fatty (cheeses) or sticky products (Arnold, Leiteritz, Zahn, \& Rohm, 2009).

\subsubsection{Meat tenderization}

The quality of meat depends on the aroma, flavor, appearance, tenderness and juiciness. Consumer behaviour has shown that tenderness is most important palatability factor in determining meat quality (Smith, Cannon, Novakofski, McKeith, \& O'Brien, 1991). The traditional method used for meat tenderization is mechanical pounding, which makes poorer quality meat more palatable. Power ultrasound has also been found to be useful for this process. Ultrasound can act in two ways: by breaking the integrity of muscular cells or by enhancing enzymatic reactions, i.e. via a biochemical effect (Boistier-Marquis, LagsirOulahal, \& Callard, 1999). A pilot study involving sirloin steak (Roberts, 1991) showed that sonicating beef muscle at $2 \mathrm{~W} \cdot \mathrm{cm}^{2}$ for $2 \mathrm{~h}$ at $40 \mathrm{kHz}$ produced damage to the perimysial connective tissue, resulting in improved eating texture.

\subsubsection{Food preservation}

Microorganisms and enzymes are the primary factors responsible of food deterioration. Conventional thermal processing kills vegetative microorganisms and some spores, and inactivates enzymes. However, the time and temperature of the process are proportional to the amount of nutrient loss, development of undesirable flavors and deterioration of functional properties of food products. Ultrasound is one of the new preservation techniques that could eliminate microbial activity. High power ultrasound alone is known to disrupt biological cells. When combined with heat treatment, it can accelerate the rate of sterilization of foods. Therefore, it reduces both the duration and intensity of the thermal treatment and the resultant damages. At sufficiently high acoustic power inputs, ultrasound is known to rupture cells (Chisti, 2003; Chisti \& Moo-Young, 1986; Dakubu, 1976). A cell can be inactivated at an intensity less than that needed to cause disruption. The mechanism of microbial killing is mainly due to the thinning of cell membranes, localized heating and production of free radicals (Butz \& Tauscher, 2002). There are many examples of microorganisms inactivated using ultrasound. Some of these have been studied in culture media and others in food, using ultrasound either combined or alone. The most frequently studied microorganisms, not only in the field of power ultrasound, but also among other methods of food preservation are Saccharomyces cerevisiae and Escherichia coli. The former has been found to be less resistant to ultrasound than other vegetative cells, which is mostly attributed to its larger size. The inactivation of this microorganism has been proven in such food models as water, phosphate buffers, and sabouraud broth (Ciccolini, Taillandier, Wilhem, Delmas, \& Strehaiano, 1997; Guerrero, LopezMalo, \& Alzamora, 2001; Petin, Zhurakovskaya, \& Komarova, 1999). The inactivation of Staphylococcus aureus, Pseudomonas fluorescens, Listeria monocytogenes and $E$. coli has been proven in water and phosphate buffers, as well as in foods such as UHT milk. Ultrasonication in combination with heat was performed to study the inactivation of Listeria innocua and mesophilic bacteria in raw whole milk. When applying ultrasound in combination with heat the kill rates were increased when compared to rates of thermal treatment alone and a synergistic rather than an additive effect was observed. Ultrasound produced a good level of inactivation under different treatment 
Version définitive du manuscrit publiée dans / Final version of the manuscript published in :

Innovative Food Science and Emerging Technologies (2017), Vol. 41, p. 357-377,

DOI: 10.1016/j.ifset.2017.04.016, Journal homepage : http://www.elsevier.com/locate/ifset

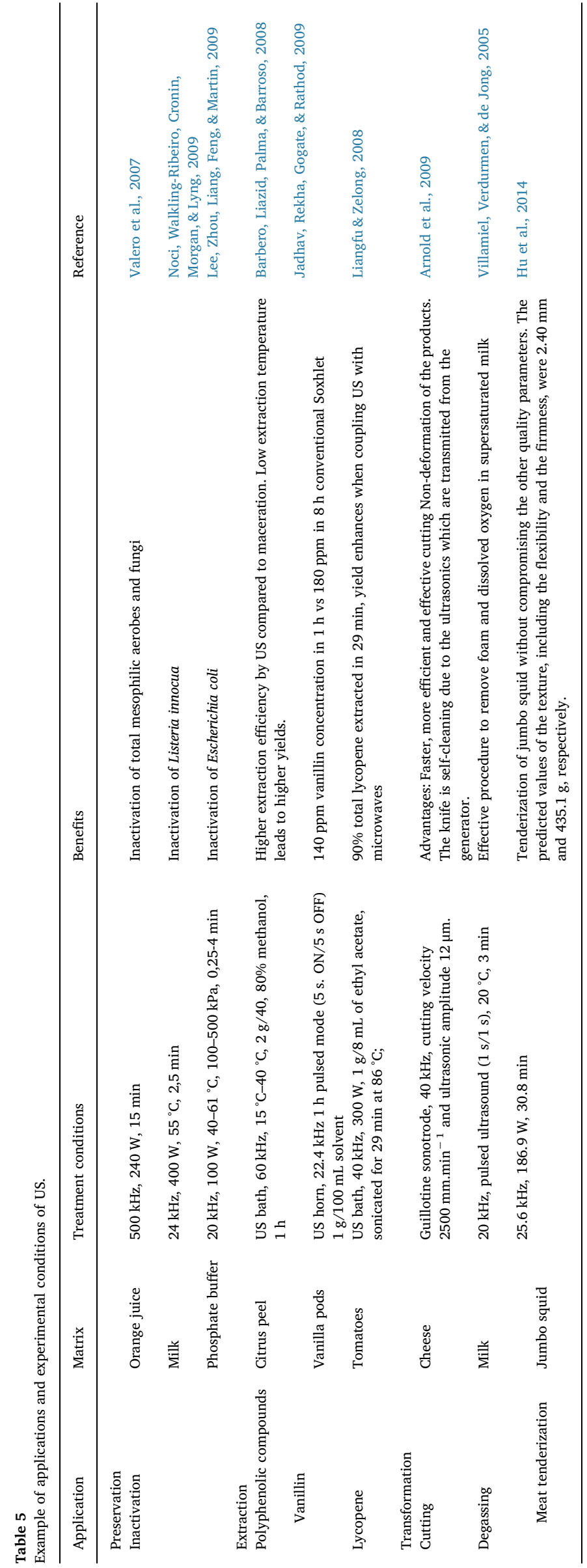

Comment citer ce document : 
Version définitive du manuscrit publiée dans / Final version of the manuscript published in :

Innovative Food Science and Emerging Technologies (2017), Vol. 41, p. 357-377,

DOI: 10.1016/j.ifset.2017.04.016, Journal homepage : http://www.elsevier.com/locate/ifset

Table 6

Characteristics, main disadvantages and advantages of green extraction techniques.

\begin{tabular}{|c|c|c|c|c|c|}
\hline Technique & Investment & Sample size & Processing time & Main disadvantages & Main advantages \\
\hline Ultrasound & Low & $600 \mathrm{~L}$ & Low & Problem for separation & High cell disruption \\
\hline Microwave & Medium & $150 \mathrm{~L}$ & Low & Hot spots & Cell disruption \\
\hline DIC & High & $100 \mathrm{~L}$ & Low & High energy consumption & High cell disruption \\
\hline SFE & High & $300 \mathrm{~L}$ & Medium & Need of know-how & Enhance mass transfer \\
\hline PEF & High & Continuous & Medium & Difficult ease of operation & Electroporation of wall cells \\
\hline
\end{tabular}

conditions and media for Bacillus species. The inactivation of Listeria monocytogenes by high-power ultrasonic waves $(20 \mathrm{kHz})$ at ambient temperature and pressure has been found to be low with decimal reduction values in $4.3 \mathrm{~min}$. This could be improved however either by an increase in pressure (manosonication) or by increasing the power of sonication. Inactivation by manothermal sonication (MTS) proved to be more effective (Manas, Pagan, Raso, Sala, \& Condon, 2000; Pagan, Manas, Alvarez, \& Condon, 1999).

For stabilization of some food materials, enzymes must be inactivated or their activity reduced. Enzyme inactivation can be easily achieved by heat treatment. However, in some cases the high heat resistance of enzymes may be a problem as heat can negatively modify some food properties such as flavor, color or nutritional value. This is the driving force for the increased interest in an alternative method of enzyme inactivation: high power ultrasound, i.e. sonic waves above $20 \mathrm{kHz}$. The effects of ultrasonic waves on proteins are very complex. Polymeric globular proteins are broken down into subunits and if oxygen is present, the quaternary structure is not recoverable. A partial delipidation of lipoproteins can be obtained and if the ultrasonic irradiation is long enough, proteins can be hydrolysed and polypeptide chains can be broken. The influence of the gas on the intensity of enzyme inactivation has been related to the formation of free radicals by cavitation. Sensitivity to ultrasounds depends on the conditions of the treatment (McClements, 1995) as well as on the nature of the enzyme. Generally, ultrasonication in combination with other treatments is more effective in food enzyme inactivation. In fact, MTS treatment has an increased effectiveness compared with ultrasound alone (Manas et al., 2000). MTS treatments inactivate several enzymes at lower temperatures and/or in a shorter time than thermal treatments at the same temperatures.

\subsubsection{Extraction}

Ultrasound assisted extraction is an emerging potential technology that can accelerate heat and mass transfer and has been successively used in extraction field. Ultrasound waves after interaction with subjected plant material alter its physical and chemical properties and their cavitational effect facilitates the release of extractable compounds and enhances the mass transport by disrupting the plant cell walls. Ultrasounds are successively employed in plant extraction field. Several classes of food components such as aromas, pigments, antioxidants, and other organic and mineral compounds have been extracted and analyzed efficiently from a variety of matrices (mainly animal tissues, food and plant materials). Riera et al. (2004) examined the effect of ultrasound $(20 \mathrm{kHz}$ and $50 \mathrm{~W})$ on the particulate almond oil extraction kinetics using supercritical $\mathrm{CO}_{2}$. As a consequence of the trials (at $280 \mathrm{bar}$ and $55{ }^{\circ} \mathrm{C}$ ) at the end of the extraction time $(8 \mathrm{~h}$ $30 \mathrm{~min}$ ) the yield of the oil was significantly increased (20\%) when SFE was assisted by ultrasound. Alternatively, mass transfer was speeded up to such an extent that yields comparable to those obtained by SFE alone could be achieved in about 30\% shorter time when using ultrasound.

\subsection{Success stories}

The considerable interest in high-powered ultrasound is due to its promising effects in food processing and preservation, such as higher product yields, shorter processing times, reduced operating and maintenance costs, improved taste, texture, flavor and color, and the reduction of pathogens at lower temperatures. It can be applied not only to improve the quality and safety of processed foods but offers the potential for developing new products with unique functionality as well. Nevertheless, although conventional cutting, emulsification and cleaning are often bottlenecks, lack of knowledge keeps industry from implementing ultrasound in their processes.

A recent survey and market study of the possible future applications of new process technologies (like microwave, ultrasound) in the food industry has revealed that many companies are reluctant to apply these new technologies. The main reason is poor understanding of these new techniques by food professionals and the reason or weight of tradition.

\section{Comparison of techniques}

The use of innovative extraction techniques such as ultrasound, microwave, instant controlled pressure drop, supercritical fluid, and pulsed electric fields (Table 6) allows reduced extraction time, energy consumed, and less water or solvent. Conventional techniques are limited by the diffusion of water or solvent into biomass, due to rigid structure of cell walls of microorganisms. The solution could be to enhance the diffusion of water or solvent and to disrupt cell walls. For example, ultrasound and electric pulse fields allow in a high disruption of cell, which permits accelerating the mass transfer, thus, processing time is reduced. In another hand, heating by microwave induces combined mass and heating transfer that permits the destruction of cells and liberation of metabolites. As a future trend is to have a decision tool which permits selecting a technology regarding the initial material. For example, the choice of which technique has to be used to perform extraction of a desired metabolite from a specific plant has to be a result of a compromise between the efficiency and reproducibility of extraction, ease of procedure, together with considerations of cost, time, safety and degree of automation.

Another challenge for the food industry in the coming years, such as consumer and society demand on one side high quality, safe, nutritional processed foods but also in another side reduction of waste and awareness about climate change. Environmental studies are difficult in particular with food products. Ideally a complete LCA study should necessarily include agricultural production, industrial refining, storage and distribution, packaging, consumption and waste management, which comprise large and complex systems (Sonnemann and Margni (2015); Peano et al. (2012); Pardo and Zufía (2012).).

\section{Conclusions and perspective}

Food processing even preservation, transformation or extraction takes an important place in manufacturing processes and is linked to several drivers such as request for naturally derived ingredients (colors, antioxidants, antimicrobial, aromas...) by the consumers, and the need of standardization. Green Food Processing could be a research thematic that encompasses a comprehensive strategy based on the discovery and the design of processes in order to reduce energy and water consumption. It has been investigated mainly at laboratory scale by several research teams in Europe mostly, and represents a good opportunity to 
Version définitive du manuscrit publiée dans / Final version of the manuscript published in :

Innovative Food Science and Emerging Technologies (2017), Vol. 41, p. 357-377,

DOI: 10.1016/j.ifset.2017.04.016, Journal homepage : http://www.elsevier.com/locate/ifset

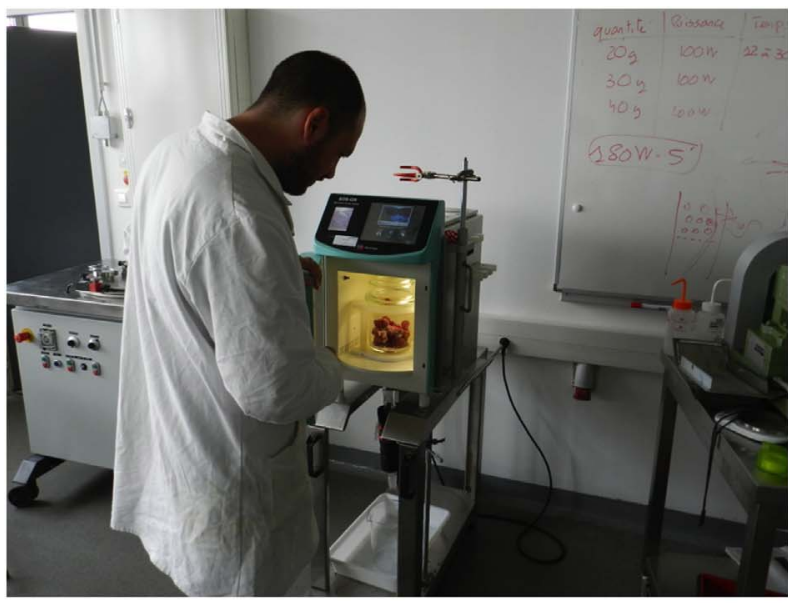

processing food especially extraction of food ingredients (aromas, colors...) with original techniques such as microwave and ultrasound (Fig. 7).

\section{References}

Abenoza, M., Benito, M., Saldaña, G., Álvarez, I., Raso, J., \& Sánchez-Gimeno, A. C. (2013). Effects of pulsed electric field on yield extraction and quality of olive oil. Food and Bioprocess Technology, 6, 1367-1373.

Abert Vian, M., Fernandez, X., Visioni, F., \& Chemat, F. (2008). Microwave hydrodiffusion and gravity: A new technique for extraction of essential oils. Journal of Chromatography. A, 1190, 14-17.

Al Bittar, S., Périno-Issartier, S., Dangles, O., \& Chemat, F. (2013). An innovative grape juice enriched in polyphenols by microwave-assisted extraction. Food Chemistry, 141, 3268-3272.

Alavi, S. H., Gogoi, B. K., Khan, M., Bowman, B. J., \& Rizvi, S. S. H. (1999). Structural properties of protein-stabilized starch-based supercritical fluid extrudates. Food Research International, 32(2), 107-118.

Allaf, T. \& Allaf, K. (Eds.), 2014. Instant controlled pressure drop (D.I.C.) in food processing, Food engineering series. Springer New York, New York, NY.

Allaf, K., \& Vidal, P. (1989). Feasibility study of a process of drying/swelling by instantaneous decompression toward vacuum of in pieces vegetables in view of rapid re-hydration gradient activity plotting. University of Technology of Compiègne UTC $\mathrm{N}^{\circ} \mathrm{CR} / 89 / 103$ industrial SILVALAON Partner.

Allaf, K., Debs-Louka, E., Louka, N., Cochet, N. \& Abraham, G. (1994). Procédé de réduction ou d'élimination d'organismes ou micro-organismes, de pasteurisation et/ ou de stérilisation et installation pour la mise en oeuvre d'un tel proécédé. FR94/ 14832.

Allaf, K., Debs-Louka, E., Louka, N., \& Abraham, G. (1998). Procédé de réduction ou d'élimination d'organismes, de microorganismes, de pasteurisation et de stérilisation des produits solides en morceaux ou pulvérulents et installation pour la mise en oeuvre d'un tel procédé. FR98/02032.

Allaf, K., Rezzoug, S.-A., Cioffi, F., Louka, N. \& Sanya, E. (1999). Procédé de traitement en vue de sécher, conserver, préserver, restaurer ou consolider le bois naturel, détérioré ou gorgé d'eau, et d'installation pour la mise en oeuvre d'un tel procédé. WO1998FR02463.

Allaf, K., Besombes, C., Berka, B., Kristiawan, M., Sobolik, V., \& Allaf, T. (2011). Enhancing extraction processes in the food industry. USA: CRC Press, 255-302.

Allaf, T., Tomao, V., Ruiz, K., Bachari, K., ElMaataoui, M., \& Chemat, F. (2013). Deodorization by instant controlled pressure drop autovaporization of rosemary leaves prior to solvent extraction of antioxidants. LWT-Food Science and Technology, $51,111-119$.

Allaf, T., Fine, F., Tomao, V., Nguyen, C., Ginies, C., \& Chemat, F. (2014). Impact of instant controlled pressure drop pre-treatment on solvent extraction of edible oil from rapeseed seeds. OCL, 21, A301.

Alonzo-Macías, M., Cardador-Martínez, A., Mounir, S., Montejano-Gaitán, G., \& Allaf, K. (2013). Comparative study of the effects of drying methods on antioxidant activity of dried strawberry (Fragaria Var. Camarosa). Journal of Food Research, 2, 92-107.

Álvarez, I., \& Heinz, V. (2007). Hurdle technology and the preservation of food by pulsed electric fields. In H. L. M. Lelieveld, \& S. Notermans (Eds.), Food preservation by pulsed electric fields: From research to application. Woodhead Publishing.

Fig. 7. Practical work on Green Food Processing for Master students at Avignon University and Introduction to green extraction for primary schools at Avignon University

rationalize eco-friendly developmental and industrial practices.

The food industry is a very competitive environment and to survive they have to use optimized processes and to reduce the carbon food print. The concept of Green Food Processing meets the demand of the final consumer in term of greener product, an education work will have to be done in order to explain what the benefits are for the final consumer. This educational work will require vulgarization from the scientific community and industry members and avoid the shortcuts of "green washing". For example, in Avignon University to illustrate an application of Green Food Processing in teaching laboratories, we used green procedures employing ultrasound energy and microwave energy as energy source to teach fundamental food processing concepts such as marinating, maceration and extraction. As an example, we have developed new green procedure, using microwave energy as energy source, to teach the fundamental concepts of extraction of essential oils used for aromatisation of food products. The objective of this teaching was to offer students the opportunity to compare the potential of this green technique for extraction of essential oil with a traditional hydrodistillation method (used in all the teaching laboratories all over the world) and to appreciate the benefits of using greener processing method: reduction in time, energy and water consumption. These green food-processing techniques could be easily understood by younger people. Each year, we open our research laboratory during the open week of "La fête de la science" and show the innovations about

Arnold, G., Leiteritz, L., Zahn, S., \& Rohm, H. (2009). Ultrasonic cutting of cheese: Composition affects cutting work reduction and energy demand. International Dairy Journal, 19, 314-320.

Badens, E. (2012). Mise en forme de principes actifs pharmaceutiques en phase supercritique. Techniques de l'ingénieur Mise en forme des médicaments, base documentaire: TIB611DUO (Ref. article: chv4010).

Bae, Y. Y., Lee, H. J., Kim, S. A., \& Rhee, M. S. (2009). Inactivation of Alicyclobacillus acidoterrestris spores in apple juice by supercritical carbon dioxide. International Journal of Food Microbiology, 136(1), 95-100.

Baier, A. K., Bußler, S., \& Knorr, D. (2015). Potential of high isostatic pressure and pulsed electric fields to improve mass transport in pea tissue. Food Research International, 76(Part 1), 66-73 Grain legumes - Science, Technology and Impacts on Human Health.

Balaban, M. O., Arreola, A. G., Marshall, M., Peplow, A., Wei, C. I., \& Cornell, J. (1991). Inactivation of pectinesterase in orange juice by supercritical carbon dioxide. Journal of Food Science, 56(3), 743-746.

Barbero, G. F., Liazid, A., Palma, M., \& Barroso, C. G. (2008). Ultrasound-assisted extraction of capsaicinoids from peppers. Talanta, 75, 1332-1337.

Bekhit, A. E.-D. A., Suwandy, V., Carne, A., Van de Ven, R., \& Hopkins, D. L. (2016). Effect of repeated pulsed electric field treatment on the quality of hot-boned beef loins and topsides. Meat Science, 111, 139-146.

Ben Haj Said, L., Bellagha, S., \& Allaf, K. (2015). Measurements of texture, sorption isotherms and drying/rehydration kinetics of dehydrofrozen-textured apple. Journal of Food Engineering, 165, 22-33.

Benaissi, K. (2013). Le CO2 supercritique appliqué à l'extraction végétale. Techniques de l'ingénieur Développement de solvants alternatifs et intensification des procédés, base documentaire: TIB492DUO (Ref. article: chv4015).

Benlloch-Tinoco, M., Martínez-Navarrete, N., \& Rodrigo, D. (2014). Impact of temperature on lethality of kiwifruit puree pasteurization by thermal and microwave processing. Food Control, 35, 22-25.

Boistier-Marquis, E., Lagsir-Oulahal, N., \& Callard, M. (1999). Applications des ultrasons de puissances en industries alimentaires. Industries Alimentaires et Agricoles, 116, 23-31. 


\section{DOI: 10.1016/j.ifset.2017.04.016, Journal homepage : http://www.elsevier.com/locate/ifset}

Boughellout, H., Choiset, Y., Rabesona, H., Chobert, J. M., Heartle, T., Mounir, S., ... Zidoune, M. N. (2015). Effect of instant controlled pressure drop (DIC) treatment on milk protein's immunoreactivity. Food and Agricultural Immunology, 26, 71-81.

Brewer, M. S., \& Begum, S. (2003). Effect of microwave power level and time on ascorbic acid content, peroxidase activity and colour of selected vegetables. Journal of Food Processing \& Preservation, 27, 411-426.

Brianceau, S., Turk, M., Vitrac, X., \& Vorobiev, E. (2015). Combined densification and pulsed electric field treatment for selective polyphenols recovery from fermented grape pomace. Innovative Food Science \& Emerging Technologies, 29, 2-8 Applications of PEF for food processing.

Brown, B., \& Goodman, J. E. (1965). High-intensity ultrasonics: Industrial applications. London: Iliffe Books.

Brown, T., James, S. J., \& Purnell, G. L. (2005). Cutting forces in foods: Experimental measurements. Journal of Food Engineering, 70, 165-170.

Brown, Z. K., Fryer, P. J., Norton, I. T., Bakalis, S., \& Bridson, R. H. (2008). Drying of foods using supercritical carbon dioxide - Investigations with carrot. Innovative Food Science \& Emerging Technologies, 9(3), 280-289.

Brunner, G. (2005). Supercritical fluids: Technology and application to food processing. Journal of Food Engineering, 67(1-2), 21-33.

Butz, P., \& Tauscher, B. (2002). Emerging technologies: Chemical aspects. Food Research International, 35, 279-284.

Catchpole, O. J., Grey, J. B., Mitchell, K. A., \& Lan, J. S. (2004). Supercritical antisolvent fractionation of propolis tincture. The Journal of Supercritical Fluids, 29(1-2), 97-106.

Chemat F., Lucchesi M. E. \& Smadja J. (2004a). Extraction sans solvant assistée par microondes de produits naturels. EP Pat. 1439218 A1.

Chemat F., Lucchesi M. E. \& Smadja J. (2004b). Solvent free microwave extraction of volatile natural substances. US Pat. 0187340 A1.

Chemat, F., Lucchesi, M., Smadja, J., Favretto, L., Colnaghi, G., \& Visioni, F. (2006). Microwave accelerated steam distillation of essential oil from lavender: A rapid, clean and environmentally friendly approach. Analysis Chimica Acta, 555, 157-160.

Chemat F., Abert-Vian M. \& Visinoni F. (2008) Microwave hydro-diffusion for isolation of natural products, European Patent. EP 1955749 A1.

Chemat, F., Tomao, V., \& Virot, M. (2008). Ultrasound-assisted extraction in food analysis. Handb. food anal. instrum. CRC Press.

Chemat, F., Huma, Z., \& Khan, M. K. (2011). Applications of ultrasound in food technology: Processing, preservation and extraction. Ultrasonics Sonochemistry, 18, 813-835.

Cheng, S. F., Mohd Nor, L., \& Chuah, C. H. (2011). Microwave pretreatment: A clean and dry method for palm oil production. Industrial Crops and Products, 34, 967-971.

Chisti, Y. (2003). Sonobioreactors: Using ultrasound for enhanced microbial productivity. Trends in Biotechnology, 21, 89-93.

Chisti, Y., \& Moo-Young, M. (1986). Disruption of microbial cells for intracellular products. Enzyme and Microbial Technology, 8, 194-204.

Ciccolini, L., Taillandier, P., Wilhem, A. M., Delmas, H., \& Strehaiano, P. (1997). Low frequency thermo ultrasonication of Saccharomyces cerevisiae suspensions: Effect of temperature and of ultrasonic power. Chemical Engineering Journal, 65, 145-149.

Cocero, M. J., Martín, Á., Mattea, F., \& Varona, S. (2009). Encapsulation and coprecipitation processes with supercritical fluids: Fundamentals and applications. The Journal of Supercritical Fluids, 47(3), 546-555.

Coronel, P., Truong, V. D., Simunovic, J., Sandeep, K. P., \& Cartwright, G. D. (2005) Aseptic processing of sweetpotato purees using a continuous flow microwave system. Journal of Food Science, 70, E531-E536.

Cuadrado, C., Cabanillas, B., Pedrosa, M. M., Muzquiz, M., Haddad, J., Allaf, K., .. Burbano, C. (2011). Effect of instant controlled pressure drop on IgE antibody reactivity to peanut, lentil, chickpea and soybean proteins. International Archives of Allergy and Immunology, 156, 397-404.

Cui, Z., Xu, S., \& Sun, D. (2003). Dehydration of garlic slices by combines microwavevacuum and air drying. Drying Technology, 21, 1173-1184.

Dakubu, S. (1976). Cell inactivation by ultrasound. Biotechnology and Bioengineering, 18, 465-471.

Damar, S., \& Balaban, M. O. (2006). Review of dense phase $\mathrm{CO}_{2}$ technology: Microbial and enzyme inactivation, and effects on food quality. Journal of Food Science, 71(1), R1-R11.

Debs-Louka, E., Louka, N., Abraham, G., \& Allaf, K. (2010). Décontamination des produits secs en morceaux ou en poudre par voie thermomécanique contrôlée. Actes 12èmes Rencontres Sci. Technol. Ind. Aliment. AGORAL Ed Lavoisier (pp. 225-230).

Díaz-Reinoso, B., Moure, A., Domínguez, H., \& Parajó, J. C. (2006). Supercritical $\mathrm{CO}_{2}$ extraction and purification of compounds with antioxidant activity. Journal of Agricultural and Food Chemistry, 54(7), 2441-2469.

Dobreva, A., Tintchev, F., Heinz, V., Schulz, H., \& Toepfl, S. (2010). Effect of pulsed electric fields (PEF) on oil yield and quality during distillation of white oil-bearing rose (Rosa alba L.). Z. Für Arznei - Gewürzpflanzen, 15, 127-132.

Drouzas, A., Tsami, E., \& Saravacos, G. D. (1999). Microwave/vacuum drying of model fruit gels. Journal of Food Engineering, 39, 117-122.

Dymek, K., Dejmek, P., Galindo, F. G., \& Wisniewski, M. (2015). Influence of vacuum impregnation and pulsed electric field on the freezing temperature and ice propagation rates of spinach leaves. LWT- Food Science and Technology, 64, 497-502.

Edgar, R. E., \& Osepchuk, J. M. (2001). Consumer, commercial and industrial microwave ovens and eating systems. In A. K. Datta, \& R. C. Anantheswaran (Eds.), Handbook of microwave technology for food applications (pp. 215-). New York: Marcel Dekker.

El Darra, N., Turk, M. F., Ducasse, M.-A., Grimi, N., Maroun, R. G., Louka, N., \& Vorobiev, E. (2016). Changes in polyphenol profiles and color composition of freshly fermented model wine due to pulsed electric field, enzymes and thermovinification pretreatments. Food Chemistry, 194, 944-950.

Eller, F. J., Taylor, S. L., \& Curren, M. S. S. (2004). Use of liquid carbon dioxide to remove hexane from soybean oil. Journal of the American Oil Chemists' Society, 81(10),

\section{9-992.}

Fathima, A., Begum, K., \& Rajalaksmi, D. (2001). Microwave drying of selected green and their sensory characteristics. Plant Foods for Human Nutrition, 56, 303-311.

Ferhat, M. A., Meklati, B. Y., Smadja, J., \& Chemat, F. (2006). An improved microwave Clevenger apparatus for distillation of essential oils from orange peel. Journal of Chromatography A, 1112, 121-126.

Fornari, T., Vicente, G., Vázquez, E., García-Risco, M. R., \& Reglero, G. (2012). Isolation of essential oil from different plants and herbs by supercritical fluid extraction. Journal of Chromatography A, 1250, 34-48.

Fraser, D. (1951). Bursting bacteria by release of gas pressure. Nature, 167(4236), 33-34.

Gachovska, T. K., Adedeji, A. A., Ngadi, M., \& Raghavan, G. V. S. (2008). Drying characteristics of pulsed electric field-treated carrot. Drying Technology, 26, 1244-1250.

Galvanin, F., De Luca, R., Ferrentino, G., Barolo, M., Spilimbergo, S. \& Bezzo, F. (2014). Bacterial inactivation on solid food matrices through supercritical CO2: A correlative study. Journal of Food Engineering, 120, 146-157.

Ganzler, K., Salgo, A., \& Valko, K. (1986). Microwave extraction. A novel sample preparation method for chromatography. Journal of Chromatography, 371, 299-306.

Garcia-Gonzalez, L., Geeraerd, A. H., Spilimbergo, S., Elst, K., Van Ginneken, L., Debevere, J., ... Devlieghere, F. (2007). High pressure carbon dioxide inactivation of microorganisms in foods: The past, the present and the future. International Journal of Food Microbiology, 117(1), 1-28.

Garcia-Gonzalez, L., Geeraerd, A. H., Elst, K., Van Ginneken, L., Van Impe, J. F., \& Devlieghere, F. (2009). Influence of type of microorganism, food ingredients and food properties on high-pressure carbon dioxide inactivation of microorganisms. International Journal of Food Microbiology, 129(3), 253-263.

Giri, S., \& Prasad, S. (2006). Modelling shrinkage and density change during microwavevacuum drying of button mushrooms. International Journal of Food Properties, 9, 409-419.

Gowen, A., Abu-Ghannam, N., Frias, J., \& Oliveira, J. (2006). Optimisation of dehydration and rehydration properties of cooked chick-peas (Cicer arietinum L.) undergoing microwave-hot air combination drying. Trends in Food Science and Technology, 17, 177-183.

Griffiths, M. W., \& Walkling-Ribeiro, M. (2014). Chapter 7 - pulsed electric field processing of liquid foods and beverages A2 - Sun, Da-Wen. Emerging technologies for food processing (pp. 115-145). (2nd ed.). San Diego: Academic Press.

Grimi, N., Lebovka, N. I., Vorobiev, E., \& Vaxelaire, J. (2009). Effect of a pulsed electric field treatment on expression behavior and juice quality of chardonnay grape. Food Biophysics, 4, 191-198.

Guerrero, S., Lopez-Malo, A., \& Alzamora, S. M. (2001). Effect of ultrasound on the survival of Saccharomyces cerevisiae: Influence of temperature, $\mathrm{pH}$ and amplitude. Innovative Food Science \& Emerging Technologies, 2, 31-39.

Gunasekaran, S. (1999). Pulsed microwave-vacuum drying of food materials. Drying Technology, 17, 395-412.

Haddad, J., Louka, N., Gadouleau, M., Juhel, F., \& Allaf, K. (2001). Application du nouveau procédé de séchage/texturation par Détente Instantanée Contrôlée DIC aux poissons: Impact sur les caractéristiques physico-chimiques du produit fini. Sciences des Aliments, 21, 481-498.

Hendrickx, M., Ludikhuyze, L., Van den Broeck, I., \& Weemaes, C. (1998). Effects of high pressure on enzymes related to food quality. Trends in Food Science \& Technology, 9(5), 197-203.

Herrero, M., Cifuentes, A., \& Ibañez, E. (2006). Sub- and supercritical fluid extraction of functional ingredients from different natural sources: Plants, food-by-products, algae and microalgae: A review. Food Chemistry, 98(1), 136-148.

Holzwarth, M., Korhummel, S., Carle, R., \& Kammerer, D. R. (2012). Evaluation of the effects of different freezing and thawing methods on color, polyphenol and ascorbic acid retention in strawberries (Fragaria $\times$ ananassa Duch.). Food Research International, 48, 241-248.

Hu, Y., Yu, H., Dong, K., Yang, S., Ye, X., \& Chen, S. (2014). Analysis of the tenderisation of jumbo squid (Dosidicus gigas) meat by ultrasonic treatment using response surface methodology. Food Chemistry, 160, 219-225.

Ignat, A., Manzocco, L., Brunton, N. P., Nicoli, M. C., \& Lyng, J. G. (2015). The effect of pulsed electric field pre-treatments prior to deep-fat frying on quality aspects of potato fries. Innovative Food Science \& Emerging Technologies, 29, 65-69 Applications of PEF For Food Processing.

Ishikawa, H., Shimoda, M., Shiratsuchi, H., \& Osajima, Y. (1995). Sterilization of microorganisms by the supercritical carbon dioxide micro-bubble method. Bioscience, Biotechnology, and Biochemistry, 59(10), 1949-1950.

Ishikawa, H., Shimoda, M., Tamaya, K., Yonekura, A., Kawano, T., \& Osajima, Y. (1997). Inactivation of bacillus spores by the supercritical carbon dioxide micro-bubble method. Bioscience, Biotechnology, and Biochemistry, 61(6), 1022-1023.

Jadhav, D., Rekha, B. N., Gogate, P. R., \& Rathod, V. K. (2009). Extraction of vanillin from vanilla pods: A comparison study of conventional Soxhlet and ultrasound-assisted extraction. Journal of Food Engineering, 93, 421-426.

Jalté, M., Lanoisellé, J.-L., Lebovka, N. I., \& Vorobiev, E. (2009). Freezing of potato tissue pre-treated by pulsed electric fields. LWT- Food Science and Technology, 42, 576-580.

Jambrak, A. R., Mason, T. J., Lelas, V., Herceg, Z., \& Herceg, I. L. (2008). Effect of ultrasound treatment on solubility and foaming properties of whey protein suspensions. Journal of Food Engineering, 86, 281-287.

Jung, J., \& Perrut, M. (2001). Particle design using supercritical fluids: Literature and patent survey. The Journal of Supercritical Fluids, 20(3), 179-219.

Kamal, I., Besombes, C., \& Allaf, K. (2014). One-step processes for in situ transesterification to biodiesel and lutein extraction from microalgae Phaeodactylum using instant controlled pressure drop (DIC). Green Processing and Synthesis, 3(6), 431-440.

Kumar, P., Coronel, P., Simunovic, J., \& Sandeep, K. P. (2007). Feasibility of aseptic 


\section{Version définitive du manuscrit publiée dans / Final version of the manuscript published in : \\ Innovative Food Science and Emerging Technologies (2017), Vol. 41, p. 357-377, \\ DOI: 10.1016/j.ifset.2017.04.016, Journal homepage : http://www.elsevier.com/locate/ifset}

processing of a low-acid multiphase food product (salsa con queso) using a continuous flow microwave system. Journal of Food Science, 72, E121-E124.

Kumar, P., Coronel, P., Truong, V. D., Simunovic, J., Swartzel, K. R., Sandeep, K. P., \& Cartwright, G. (2008). Overcoming issues associated with the scaleup of a continuous flow microwave system for aseptic processing of vegetable pureess. Food Research International, 41, 454-461.

Laborde, J. L., Bouyer, C., Caltagirone, J.-P., \& Gerard, A. (1998). Acoustic bubble cavitation at low frequencies. Ultrasonics, 36, 589-594.

Lane, D., \& Jenkins, S. W. D. (1984). Presented at the 9th International Symposium on Polynuclear Aromatic Hydrocarbons, Columbus, $\mathrm{OH}$. (Abstracts, 437).

Lebovka, N. I., Praporscic, I., \& Vorobiev, E. (2004). Effect of moderate thermal and pulsed electric field treatments on textural properties of carrots, potatoes and apples. Innovative Food Science \& Emerging Technologies, 5, 9-16.

Lee, H., Zhou, B., Liang, W., Feng, H., \& Martin, S. E. (2009). Inactivation of Escherichia coli cells with sonication, manosonication, thermosonication, and

manothermosonication: Microbial responses and kinetics modelling. Journal of Food Engineering, 93, 354-364.

Leo, L., Rescio, L., Ciurlia, L., \& Zacheo, G. (2005). Supercritical carbon dioxide extraction of oil and a-tocopherol from almond seeds. Journal of the Science of Food and Agriculture, 85(13), 2167-2174.

Leong, S. Y., Richter, L.-K., Knorr, D., \& Oey, I. (2014). Feasibility of using pulsed electric field processing to inactivate enzymes and reduce the cutting force of carrot (Daucus carota Var. Nantes). Innovative Food Science \& Emerging Technologies, 26, 159-167.

Leong, S.-Y., Oey, I., Clapperton, D., Aganovic, K., \& Toepfl, S. (2015). Chilling prior to low intensity pulsed electric field processing improved vitamin C stability of carrot puree (Daucus carota cv. Nantes). International Journal of Food Science and Technology, $50,1757-1763$.

Liangfu, Z., \& Zelong, L. (2008). Optimization and comparison of ultrasound/microwave assisted extraction (UMAE) and ultrasonic assisted extraction (UAE) of lycopene from tomatoes. Ultrasonics Sonochemistry, 15, 731-737.

Lin, S., \& Brewer, S. M. (2005). Effects of blanching method on the characteristics of frozen peas. Journal of Food Quality, 28, 350-360.

Liu, X., Gao, Y., Xu, H., Hao, Q., Liu, G., \& Wang, Q. (2010). Inactivation of peroxidase and polyphenol oxidase in red beet (Beta vulgaris L.) extract with continuous high pressure carbon dioxide. Food Chemistry, 119(1), 108-113.

Loginova, K., Loginov, M., Vorobiev, E., \& Lebovka, N. I. (2011). Quality and filtration characteristics of sugar beet juice obtained by "cold" extraction assisted by pulsed electric field. Journal of Food Engineering, 106, 144-151.

Lumia, G. (2011). Extraction par fluides supercritiques. In F. Chemat (Ed.), Eco-extraction du végétal (pp. 231-258). Paris: Dunod.

Macedo, S., Fernandes, S., Lopes, J. A., de Sousa, H. C., Pereira, P. J., Carmelo, P. J., Nunes da Ponte, M. (2008). Recovery of wine-must aroma compounds by supercritical $\mathrm{CO}_{2}$. Food and Bioprocess Technology, 1(1), 74-81.

Manas, P., Pagan, R., Raso, J., Sala, F. J., \& Condon, S. (2000). Inactivation of Salmonella enteridis, Salmonella typhimurium and Salmonella seftenberg by ultrasonic waves under pressure. Journal of Food Protection, 63, 451-456.

Martín-Belloso, O., Marsellés-Fontanet, Á. R., \& Elez-Martínez, P. (2014). Chapter 9 enzymatic inactivation by pulsed electric fields A2 - Sun, Da-Wen. Emerging technologies for food processing (pp. 155-168). (2nd ed.). San Diego: Academic Press.

Maskan, M., \& Altan, A. (2011). Advances in food extrusion technology. Boca Raton, Florida, USA: CRC Press.

Mattar, J. R., Turk, M. F., Nonus, M., Lebovka, N. I., El Zakhem, H., \& Vorobiev, E. (2015). S. cerevisiae Fermentation activity after moderate pulsed electric field pre-treatments. Bioelectrochemistry, 103, 92-97 BIOELECTRICS 2013.

McClements, D. J. (1995). Advances in the application of ultrasound in food analysis and processing. Trends in Food Science and Technology, 6, 293-299.

McDonnell, C. K., Allen, P., Chardonnereau, F. S., Arimi, J. M., \& Lyng, J. G. (2014). The use of pulsed electric fields for accelerating the salting of pork. LWT-Food Science and Technology, 59, 1054-1060.

Megahey, E. K., Mcminn, W. A. M., \& Magee, T. R. A. (2005). Experimental study of microwave baking of Madeira cake batter. Food and Bioproducts Processing, 83, 277-287.

Mellouk, H., Meullemiestre, A., Maache-Rezzoug, Z., Allaf, K., \& Rezzoug, S.-A. (2013). Isolation of volatiles from oak wood (Quercus alba) by a thermomechanical process: Screening of some processing parameters. Separation Science and Technology, 48, 1851-1858.

Melo Silva, J., Rigo, A. A., Dalmolin, I. A., Debien, I., Cansian, R. L., Oliveira, J. V., \& Mazutti, M. A. (2013). Effect of pressure, depressurization rate and pressure cycling on the inactivation of Escherichia coli by supercritical carbon dioxide. Food Control, 29(1), 76-81.

Mettin, R. (2005). Bubble structures in acoustic cavitation. In A. A. Doinikov (Ed.), Bubble and particle dynamics in acoustic fields: Modern trends and applications (pp. 1-36). Kerala: Research Signpost.

Mezzomo, N., Paz, E.d., Maraschin, M., Martín, Á., Cocero, M. J., \& Ferreira, S. R. S (2012). Supercritical anti-solvent precipitation of carotenoid fraction from pink shrimp residue: Effect of operational conditions on encapsulation efficiency. The Journal of Supercritical Fluids, 66, 342-349.

Miguel, F., Martín, A., Gamse, T., \& Cocero, M. J. (2006). Supercritical anti solvent precipitation of lycopene: Effect of the operating parameters. The Journal of Supercritical Fluids, 36(3), 225-235.

Mkaouar, S., Bahloul, N., Gelicus, A., Allaf, K., \& Kechaou, N. (2015). Instant controlled pressure drop texturing for intensifying ethanol solvent extraction of olive (Olea europaea) leaf polyphenols. Separation and Purification Technology, 145, 139-146.

Monteiro, R. L., Carciofi, B. A. M., \& Laurindo, J. B. (2016). A microwave multi-flash drying process for producing crispy bananas. Journal of Food Engineering, 178, 1-11.

Mounir, S., \& Allaf, K. (2008). Three-stage spray drying: New process involving instant controlled pressure drop. Drying Technology, 26, 452-463.

Mounir, S., Besombes, C., Al-Bitar, N., \& Allaf, K. (2011). Study of instant controlled pressure drop DIC treatment in manufacturing snack and expanded granule powder of apple and onion. Drying Technology, 29, 331-341.

Mukhopadhyay, M., \& Singh, S. (2004). Refining of crude lecithin using dense carbon dioxide as anti-solvent. The Journal of Supercritical Fluids, 30(2), 201-211.

Nguyen Van, C. (2010). Maîtrise de l'aptitude technologique des oléagineux par modification structurelle: applications aux opérations d'extraction et de transestérification in-situ. Thèse de l'Université de La Rochelle.

Noci, F., Walkling-Ribeiro, M., Cronin, D. A., Morgan, D. J., \& Lyng, J. G. (2009). Effect of thermosonication, pulsed electric field and their combination on inactivation of Listeria innocua in milk. International Dairy Journal, 19, 30-35.

Pagan, R., Manas, P., Alvarez, I., \& Condon, S. (1999). Resistance of Listeria monocytogenes to ultrasonic waves under pressure at sublethal (manosonication) and lethal (manothermosonication) temperatures. Food Microbiology, 16, 139-148.

Palma, M., Taylor, L. T., Varela, R. M., Cutler, S. J., \& Cutler, H. G. (1999). Fractional extraction of compounds from grape seeds by supercritical fluid extraction and analysis for antimicrobial and agrochemical activities. Journal of Agricultural and Food Chemistry, 47(12), 5044-5048.

Paniwnyk, L. (2005). Applications of ultrasound. In D.-W. Sun (Vol. Ed.), Emerging technologies for food processing. 323-352. Amsterdam: Elsevier.

Pardo, G., \& Zufía, J. (2012). Life cycle assessment of food-preservation technologies. Journal of Cleaner Production, 28, 198-207.

Parniakov, O., Bals, O., Lebovka, N., \& Vorobiev, E. (2016a). Effects of pulsed electric fields assisted osmotic dehydration on freezing-thawing and texture of apple tissue. Journal of Food Engineering, 183, 32-38.

Parniakov, O., Bals, O., Lebovka, N., \& Vorobiev, E. (2016b). Pulsed electric field assisted vacuum freeze-drying of apple tissue. Innovative Food Science \& Emerging Technologies, 35, 52-57.

Peano, L., Schryver, A. D., Humbert, S., Loerincik, Y., Gaillard, G., Lansche, J., \& Nemecek, T. (2012). The World Food LCA Database project: Towards more accurate food datasets. Proceedings 2nd LCA conference.

Périno-Issartier, S., Giniès, C., Cravotto, G., \& Chemat, F. (2013). Comparison of essential oils from lavandin obtained by different extraction processes: Ultrasound, microwave, turbohydrodistillation, steam and hydrodistillation. Journal of Chromatography A, 1305, 41-47.

Perrut, M. (2012). Sterilization and virus inactivation by supercritical fluids (a review). The Journal of Supercritical Fluids, 66, 359-371.

Petin, V. G., Zhurakovskaya, G. P., \& Komarova, L. N. (1999). Mathematical description of combined action of ultrasound and hyperthermia on yeast cells. Ultrasonics, 37, 79-83.

Phoon, P. Y., Galindo, F. G., Vicente, A., \& Dejmek, P. (2008). Pulsed electric field in combination with vacuum impregnation with trehalose improves the freezing tolerance of spinach leaves. Journal of Food Engineering, 88, 144-148.

Puértolas, E., Luengo, E., Álvarez, I., \& Raso, J. (2012). Improving mass transfer to soften tissues by pulsed electric fields: Fundamentals and applications. Annual Review of Food Science and Technology, 3, 263-282.

Rastogi, N.k., Eshtiaghi, M.n., \& Knorr, D. (1999). Accelerated mass transfer during osmotic dehydration of high intensity electrical field pulse pretreated carrots. Journal of Food Science, 64, 1020-1023.

Rawson, F. F. (1988). An introduction to ultrasonic food cutting AQ4. In M. J. W. Povey, \& T. J. Mason (Eds.), Ultrasound in food processing. Glasgow: Blackie.

Reverchon, E. (1997). Supercritical fluid extraction and fractionation of essential oils and related products. The Journal of Supercritical Fluids, 10(1), 1-37.

Reverchon, E. (1999). Supercritical antisolvent precipitation of micro- and nano-particles. The Journal of Supercritical Fluids, 15(1), 1-21.

Reverchon, E., \& Adami, R. (2006). Nanomaterials and supercritical fluids. The Journal of Supercritical Fluids, 37(1), 1-22.

Reverchon, E., \& De Marco, I. (2006). Supercritical fluid extraction and fractionation of natural matter. The Journal of Supercritical Fluids, 38(2), 146-166.

Riera, E., Golás, Y., Blanco, A., Gallego, J. A., Blasco, M., \& Mulet, A. (2004). Mass transfer enhancement in supercritical fluids extraction by means of power ultrasound. Ultrasonics Sonochemistry, 11, 241-244.

Rizvi, S. S. H., Mulvaney, S. J., \& Sokhey, A. S. (1995). The combined application of supercritical fluid and extrusion technology. Trends in Food Science \& Technology, 6(7), 232-240.

Roberts, R. T. (1991). Sound for processing food. Nutr. Food Sci. 91, 18-19.

Robinson, C. W., Siegel, M. H., Condemine, A., Fee, C., Fahidy, T. Z., \& Glick, B. R. (1993) Pulsed-electric-field crossflow ultrafiltration of bovine serum albumin. Journal of Membrane Science, 80, 209-220.

Rodríguez-Meizoso, I., \& Plaza, M. (2015). Particle formation of food ingredients by supercritical fluid technology. In T. Fornari, \& P. R. Stateva (Eds.), High pressure fluid technology for green food processing (pp. 155-183). Cham: Springer International Publishing.

Roodenburg, B., De Haan, S. W. H., Ferreira, J. A., Coronel, P., Wouters, P. C., \& Hatt, V. (2013). Toward $6 \log 10$ pulsed electric field inactivation with conductive plastic packaging material. Journal of Food Process Engineering, 36, 77-86.

Rozzi, N. L., \& Singh, R. K. (2002). Supercritical fluids and the food industry. Comprehensive Reviews in Food Science and Food Safety, 1(1), 33-44.

Rozzi, N. L., Singh, R. K., Vierling, R. A., \& Watkins, B. A. (2002). Supercritical fluid extraction of lycopene from tomato processing byproducts. Journal of Agricultural and Food Chemistry, 50(9), 2638-2643.

Santos, D. T., Albarelli, J. Q., Beppu, M. M., \& Meireles, M. A. A. (2013). Stabilization of anthocyanin extract from jabuticaba skins by encapsulation using supercritical $\mathrm{CO}_{2}$ as solvent. Food Research International, 50(2), 617-624.

Sanya, E., Rezzoug, S.-A., \& Allaf, K. (1998). Mise au point d'un nouveau procédé de 
Version définitive du manuscrit publiée dans / Final version of the manuscript published in :

Innovative Food Science and Emerging Technologies (2017), Vol. 41, p. 357-377,

\section{DOI: 10.1016/j.ifset.2017.04.016, Journal homepage : http://www.elsevier.com/locate/ifset}

restauration et de conservation de bois gorgés d'eau: Imprégnation à l'amidon couplée à un traitement thermomécanique. Final European Meeting on ARKE project. France: Marseille.

Sarrade, S. J., Rios, G. M., \& Carlès, M. (1998). Supercritical $\mathrm{CO}_{2}$ extraction coupled with nanofiltration separation: Applications to natural products. Separation and Purification Technology, 14(1-3), 19-25.

Saulis, G. (2010). Electroporation of cell membranes: The fundamental effects of pulsed electric fields in food processing. Food Engineering Reviews, 2, 52-73.

Schiffmann, R. F. (2001). Microwave processes for the food industry. In A. K. Datta, \& R. C. Anantheswaran (Eds.), Handbook of microwave technology for food applications (pp. 299-). New York: Marcel Dekker.

Schmid, A. H., Dolan, K. D., \& Ng, P. K. W. (2005). Effect of extruding wheat flour at lower temperatures on physical attributes of extrudates and on thiamin loss when using carbon dioxide gas as a puffing agent. Cereal Chemistry Journal, 82(3), 305-313.

Schneider, Y., Zahn, S., \& Rohm, H. (2008). Power requirements of the high frequency generator in ultrasonic cutting of foods. Journal of Food Engineering, 86, 61-67.

Schneider, Y., Zahn, S., Schindler, C., \& Rohm, H. (2009). Ultrasonic excitation affects friction interactions between food materials and cutting tools. Ultrasonics, 49, 588-593.

Scotto A.(1988) Device for demoulding industrial food products, Fr. Pat. FR 2604063

Shayanfar, S., Chauhan, O., Toepfl, S., \& Heinz, V. (2013). The interaction of pulsed electric fields and texturizing - antifreezing agents in quality retention of defrosted potato strips. International Journal of Food Science and Technology, 48, 1289-1295.

Shimoda, M., Yamamoto, Y., Cocunubo-Castellanos, J., Yoshimura, T., Miyake, M., Ishikawa, H., \& Osajima, Y. (2000). Deodorization of fish sauce by continuous-flow extraction with microbubbles of supercritical carbon dioxide. Journal of Food Science, 65(8), 1349-1351.

Siemer, C., Toepfl, S., \& Heinz, V. (2014). Inactivation of Bacillus subtilis spores by pulsed electric fields (PEF) in combination with thermal energy - I. Influence of process- and product parameters. Food Control, 39, 163-171.

Siemer, Aganovic, K., Toepfl, S., \& Heinz, V. (2015). Application of pulsed electric fields in food. In S. Bhattacharya (Ed.), Conventional and advanced food processing technologies, food science \& technology (pp. 645-672).

Smith, N. B., Cannon, J. E., Novakofski, J. E., McKeith, F. K., \& O'Brien, W. D., Jr. (1991). Tenderization of semitendinosus muscle using high intensity ultrasound. Ultrason. Symp. 1371-1374.

Sonnemann, G., \& Margni, M. (2015). LCA compendium - The complete world of life cycle assessment. New York: Springer.

Sovová, H., Aleksovsk, S. A., Bocevska, M., \& Stateva, R. P. (2006). Supercritical fluid extraction of essential oils results of joint research. Chemical Industry and Chemical Engineering Quarterly, 12, 168-174.

Spilimbergo, S., Elvassore, N., \& Bertucco, A. (2002). Microbial inactivation by highpressure. The Journal of Supercritical Fluids, 22(1), 55-63.

Steed, L. E., Truong, V. D., Simunovic, J., Sandeep, K. P., Kumar, P., Cartwright, G. D., \& Swartzel, K. R. (2008). Continuous flow microwave-assisted processing and aseptic packaging of purple-fleshed sweetpotato purees. Journal of Food Science, 73, E455.

Sumnu, G. (2001). A review on microwave baking of foods. International Journal of Food Science and Technology, 36, 117-127.

Tedjo, W., Eshtiaghi, M. N., \& Knorr, D. (2000). Impact of supercritical carbon dioxide and high pressure on lipoxygenase and peroxidase activity. Journal of Food Science, 65(8), 1284-1287.

Temelli, F. (2009). Perspectives on supercritical fluid processing of fats and oils. The Journal of Supercritical Fluids, 47(3), 583-590.

Terefe, N. S., Buckow, R., \& Versteeg, C. (2015). Quality-related enzymes in plant-based products: Effects of novel food processing technologies part 2: Pulsed electric field processing. Critical Reviews in Food Science and Nutrition, 55, 1-15.

Tervo, J. T., Mettin, R., \& Lauterborn, W. (2006). Bubble cluster dynamics in acoustic cavitation. Acta Acust. Acust. 92, 178-180.

Therdthai, N., \& Zhou, W. B. (2003). Recent advances in the studies of bread baking process and their impact on the bread baking technology. Food Science and Technology Research, 9, 219-226.

Toepfl, S. (2012). Pulsed electric field food processing - industrial equipment design and commercial applications. Stewart Postharvest Rev. 8, 1-7.
Toepfl, S., Heinz, V., \& Knorr, D. (2006). Applications of pulsed electric fields technology for the food industry. In J. Raso, \& V. Heinz (Eds.), Food engineering series. (pp. $197-$ 221). Springer US.

Toepfl, S., Siemer, C., \& Heinz, V. (2014). Chapter 8 - effect of high-intensity electric field pulses on solid foods A2 - Sun, Da-Wen. Emerging technologies for food processing (pp. 147-154). (2nd ed.). San Diego: Academic Press.

Tokusoglu, Ö., Odriozola-Serrano, I., \& Martín-Belloso, O. (2014). Quality, safety, and shelf-Life improvement in fruit juices by pulsed electric fields. Improving food quality with novel food processing technologies (pp. 385-). 412: CRC Press.

Torres, C. F., Torrelo, G., Señoráns, F. J., \& Reglero, G. (2009). Supercritical fluid fractionation of fatty acid ethyl esters from butteroil. Journal of Dairy Science, 92(5), 1840-1845.

Turk, M. F., Vorobiev, E., \& Baron, A. (2012). Improving apple juice expression and quality by pulsed electric field on an industrial scale. LWT-Food Science and Technology, 49, 245-250 Euro-Mediterranean Symposium on Fruit and Vegetable Processing.

Valero, M., Recrosio, N., Saura, D., Munoz, N., Martic, N., \& Lizama, V. (2007). Effects of ultrasonic treatments in orange juice processing. Journal of Food Engineering, 80 509-516.

Van den Bosch, H. F. M. (2007). Chamber design and process conditions for pulsed electric field treatment of food. Woodhead Publishing series in food science, technology and nutrition. (pp. 70-93). Woodhead Publishing.

Venter, M. J., Willems, P., Kuipers, N. J. M., \& Haan, A. B.d. (2006). Gas assisted mechanical expression of cocoa butter from cocoa nibs and edible oils from oilseeds. The Journal of Supercritical Fluids, 37(3), 350-358.

Villamiel, M., Verdurmen, R., \& de Jong, P. (2005). Degassing of milk by high-intensity ultrasound. Milchwissenschaft, 55, 123-125.

Vina, S. Z., Olivera, D. F., Marani, C. M., Ferreyra, R. M., Mugridge, A., Chaves, A. R., \& Mascheroni, R. H. (2007). Quality of Brussels sprouts as affected by blanching method. Journal of Food Engineering, 80, 218-222.

Visentin, A., Rodríguez-Rojo, S., Navarrete, A., Maestri, D., \& Cocero, M. J. (2012) Precipitation and encapsulation of rosemary antioxidants by supercritical antisolvent process. Journal of Food Engineering, 109(1), 9-15.

Voges, S., Eggers, R., \& Pietsch, A. (2008). Gas assisted oilseed pressing. Separation and Purification Technology, 63(1), 1-14.

Vorobiev, E., \& Lebovka, N. (2009). Electrotechnologies for extraction from food plants and biomaterials. Food engineering series. New York, NY: Springer New York.

Vorobiev, E., \& Lebovka, N. (2015). Selective extraction from food plants and residues by pulsed electric field. In F. Chemat, \& J. Strube (Eds.), Process engineering. (pp. 307332). (Germany).

Wei, C. I., Balaban, M. O., Fernando, S. Y., \& Peplow, A. J. (1991). Bacterial effect of high pressure $\mathrm{CO}_{2}$ treatment on foods spiked with listeria or salmonella. Journal of Food Protection, 54(3), 189-193.

Weidner, E. (2009). High pressure micronization for food applications. The Journal of Supercritical Fluids, 47(3), 556-565.

Wiktor, A., Śledź, M., Nowacka, M., Chudoba, T., \& Witrowa-Rajchert, D. (2014). Pulsed electric field pretreatment for osmotic dehydration of apple tissue: Experimental and mathematical modeling studies. Drying Technology, 32, 408-417.

Willems, P., Kuipers, N. J. M., \& de Haan, A. B. (2008). Gas assisted mechanical expression of oilseeds: Influence of process parameters on oil yield. The Journal of Supercritical Fluids, 45(3), 298-305.

Wimmer, Z., \& Zarevúcka, M. (2010). A review on the effects of supercritical carbon dioxide on enzyme activity. International Journal of Molecular Sciences, 11(1), 233-253.

Won, Y.-C., Min, S. C., \& Lee, D.-U. (2015). Accelerated drying and improved color properties of red pepper by pretreatment of pulsed electric fields. Drying Technology, 33, 926-932.

Wu, Y., \& Zhang, D. (2014). Effect of pulsed electric field on freeze-drying of potato tissue. International Journal of Food Engineering, 10, 857-862.

Yangyang, X., Mujumdar, A. S., Le-qun, Z., \& Jin-cai, S. (2004). Studies on hot air and microwave vacuum drying of wild cabbage. Drying Technology, 22, 2201-2209.

Yongsawatdigul, J., \& Gunasekaran, S. (1996). Microwave vacuum drying of cranberries, part II: Quality evaluation. Journal of Food Processing and Preservation, 20, 145-156. 